(C) The Author(s), 2022. Published by Cambridge University Press on behalf of British Institute of International and Comparative Law. This is an Open Access article, distributed under the terms of the Creative Commons Attribution-NonCommercial-NoDerivatives licence (https://creativecommons.org/ licenses/by-nc-nd/4.0/), which permits non-commercial re-use, distribution, and reproduction in any medium, provided the original work is unaltered and is properly cited. The written permission of Cambridge University Press must be obtained for commercial re-use or in order to create a derivative work.

\title{
PROTECTING FOREIGN INVESTMENT AND PUBLIC HEALTH THROUGH ARBITRAL BALANCING AND TREATY DESIGN
}

\author{
Freya BAETENS*
}

\begin{abstract}
This article analyses the fraught relationship between host States' obligations under investment agreements and their regulatory powers in the field of public health. First, tribunals addressing the merits of health measures have exercised considerable deference to States under existing treaties. Second, the recent generation of treaties spells out health considerations to encourage respondents or tribunals to adopt broad interpretations of the right to regulate, general exceptions, or articlespecific carve-outs. Clauses modelled on GATT exceptions may prove difficult to invoke due to the 'necessity' threshold. Finally, the Kyoto Protocol may serve as a model of incentivising private investment in the public health sector.
\end{abstract}

Keywords: public health, foreign investment, access to medicine, right to regulate, intellectual property, general exceptions, police powers, margin of appreciation, necessity.

\section{INTRODUCTION}

The COVID-19 pandemic has focussed attention on the appropriate balance between public interests, notably health, and the interests of investors. ${ }^{1}$ This article explores the relationship — at times fraught — between the obligations of host States under International Investment Agreements (IIAs) and their regulatory powers in the field of public health. First, it considers investment case law under existing treaties and examines cases that have directly addressed public health, as well as the legal bases and the tribunals'

* Professor of Public International Law at the PluriCourts Centre of Excellence, Faculty of Law, Oslo University; affiliated with the Europa Institute, Faculty of Law, Leiden University; Member of the Brussels Bar. This work was partly supported by the Research Council of Norway through its Centres of Excellence funding scheme (project number 223274) and the FRIPRO Young Research Talents (project number 274946). The author would like to thank Oliver Hailes for his research assistance and Valentina Vadi, Tania Voon, Caroline Henckels and Andrew Mitchell for their feedback.

1 See eg J Arato, K Claussen and J Benton Heath, 'The Perils of Pandemic Exceptionalism' (2020) 114 AJIL 627; S Murase (Rapporteur of the 12th Commission), 'Epidemics and International Law' (2021) 81 Annuaire de l'Institut de Droit International 37, paras 87-90. See generally V Vadi, Public Health in International Investment Law and Arbitration (Routledge 2013). On the framing of pandemics as biological and social events, and potential implications for international adjudication, see F Paddeu and M Waibel, 'The Final Act: Exploring the End of Pandemics' (2020) 114 AJIL 698. 
reasoning for doing so. Secondly, the article scrutinises the new generation of IIAs and Free Trade Agreements (FTAs) that include provisions dealing with public health in their investment chapters. Thirdly, the article assesses the treaties more broadly: it examines whether past cases would have been decided differently under the new generation of investment treaties, evaluates the relationship between public health measures and intellectual property rights, and discusses a possible alternative to the dominant nexus requirement of 'necessity', this being an exception for measures 'related to' public health.

In its conclusion, the article investigates how, similar to the incentive model pioneered by the Kyoto Protocol with regard to renewable energy investment, international law could actively promote private investment in furtherance of global public health objectives, for example in the context of a global pandemic. ${ }^{2}$ Such health objectives can be realised only through reasonable regulatory measures that harness the material resources of the global private sector for the purposes of socially beneficial economic activities while also protecting human health. ${ }^{3}$ At present, IIAs and investor-State arbitration remain vital mechanisms of international law which must balance the potentially conflicting objectives of investment protection and public health. The alternative would be to redesign the relationship between these objectives through far-reaching investment treaty reform or a novel agreement on public health. ${ }^{4}$

\section{PUBLIC HEALTH IN INVESTMENT DISPUTES UNDER EXISTING TREATIES}

Investment treaties concluded before 2015 generally do not refer to public health. ${ }^{5}$ As a result, whenever this has arisen in investment proceedings, it has been left to the arbitral tribunals to weigh public health against the interests that are explicitly protected under the investment treaties. Investor-

2 See eg UNGA Res 70/1, 'Transforming Our World: The 2030 Agenda for Sustainable Development' (25 September 2015) UN Doc A/RES/70/1, 16-17 (Goal 3. Ensure healthy lives and promote well-being for all at all ages). See also discussions concerning the development of a new legal framework for epidemic prevention: J Viñuales et al., 'A Global Pandemic Treaty Should Aim for Deep Prevention' (2021) 397 Lancet 1791.

3 Before the COVID-19 pandemic, the annual investment gap to achieve the Sustainable Development Goals (SDGs) in developing countries was estimated to be USD 2.5 trillion, which widened by USD 1.7 trillion in 2020 due to a shortfall in health spending amid increased needs in those countries: see OECD, Global Outlook on Financing for Sustainable Development 2021: A New Way to Invest for People and Planet (OECD 2020).

4 The nexus between foreign investment and SDG 3 Health is further explored in F Baetens, 'Sustainable Development Goal 3: Reconciling Private Investment Protection and Public Health Objectives' in S Stephenson and M-C Cordonier Segger (eds), Research Handbook on Investment Law and Sustainable Development (Edward Elgar forthcoming).

5 There are notable exceptions, including the first modern BIT: see Treaty between the Federal Republic of Germany and Pakistan for the Promotion and Protection of Investments (adopted 25 November 1959, entered into force 28 April 1962) 457 UNTS 24, Protocol ('Measures taken for reasons of ... public health ... shall not be deemed as discrimination within the meaning of Article 2'). 
State arbitral tribunals have dealt with a number of investor claims and host State defences based on public health grounds. Such States include both developed and developing countries, and the grounds invoked relate to a wide variety of public health matters. These grounds are categorised and analysed below as cases where investor interests were arguably pitted against, first, health warnings and plain packaging rules (subsection 1); secondly, measures promoting access to medicine (subsection 2); and, thirdly, environment-related health measures (subsection 3). Catalogued in a Table in subsection 4, these cases comprise all known publicly available decisions that directly address issues of public health, with the obvious caveat that the notion of public health is itself open to debate both as an analytical category and as a question of treaty interpretation. ${ }^{6}$

\section{A. Health Warnings and Plain Packaging Rules}

On 21 May 2003, the World Health Assembly adopted the World Health Organization (WHO) Framework Convention on Tobacco Control (FCTC), the first international agreement negotiated under the auspices of the WHO. ${ }^{7}$ It entered into force on 27 February 2005 and, at the time of writing, has 182 Parties covering more than 90 per cent of the world's population. ${ }^{8}$ The FCTC is intended to be a milestone in the promotion of public health and to further develop the legal framework for international health cooperation. In the wake of this Framework Convention, and in the context of debates taking place at international, regional and domestic levels, several countries moved towards the adoption of so-called 'plain packaging rules'.

The WHO has defined plain (or standardised) packaging as 'measures to restrict or prohibit the use of logos, colours, brand images or promotional information on packaging other than brand names and product names displayed in a standard colour and font style (plain packaging)'. ${ }^{9}$ Plain packaging serves several purposes, including 'reducing the attractiveness of

\footnotetext{
${ }^{6}$ See further section IV below, discussing the demarcation of public health measures.

7 World Health Organization Framework Convention on Tobacco Control (adopted 21 May 2003, entered into force 27 February 2005) 2302 UNTS 166.

${ }^{8}$ World Health Organization (WHO), 'Parties to the WHO Framework Convention on Tobacco Control' < https://www.who.int/fctc/cop/en>.

9 WHO, 'Guidelines for Implementation of Article 11 of the WHO Framework Convention on Tobacco Control (Packaging and Labelling of Tobacco Products)' $<$ https://www.who.int/fctc/ guidelines/article_11.pdf?ua=1>. See also WHO, 'Guidelines for Implementation of Article 13 of the WHO Framework Convention on Tobacco Control (Tobacco Advertising, Promotion and Sponsorship)' <https://www.who.int/fctc/guidelines/article_13.pdf?ua=1>, which describe plain packaging as: 'black and white or two other contrasting colours, as prescribed by national authorities; nothing other than a brand name, a product name and/or manufacturer's name, contact details and the quantity of product in the packaging, without any logos or other features apart from health warnings, tax stamps and other government-mandated information or markings; prescribed font style and size; and standardized shape, size and materials. There should be no advertising or promotion inside or attached to the package or on individual cigarettes or other tobacco products.'
} 
tobacco products; eliminating the effects of tobacco packaging as a form of advertising and promotion; addressing package design techniques that may suggest that some products are less harmful than others; and increasing the noticeability and effectiveness of health warnings.' ${ }^{10}$ In 2012, Australia became the first country to implement laws requiring plain packaging of tobacco products. ${ }^{11}$ Since then, Belgium, Canada, France, Hungary, Ireland, Israel, the Netherlands, New Zealand, Norway, Saudi Arabia, Singapore, Slovenia, Thailand, Turkey, the United Kingdom and Uruguay have implemented legislation while other countries, including Chile, Ecuador, Panama and South Africa have initiated legislative processes in this regard. ${ }^{12}$

These developments were not, however, universally welcomed: perhaps unsurprisingly, the tobacco industry mounted a counterattack arguing that plain packaging would breach their intellectual property rights and infringe international trade agreements, as well as the EU Principles of Better Regulation. ${ }^{13}$ Moreover, tobacco companies argued that there was no credible evidence that plain packaging would be effective in achieving its stated goals and that many countries had already dropped the idea. Finally, they feared that plain packaging would lead to increased smuggling of counterfeit cigarettes, that it would be costly, and that it would be extended to other products.

Amidst this discussion, one tobacco company, Philip Morris, decided to launch international arbitral proceedings against two States that had imposed restrictive regulations on tobacco packaging: Australia and Uruguay. ${ }^{14}$ Before Australia had adopted its plain packaging rules, Uruguay had already enacted an Ordinance requiring each cigarette brand to have a 'single presentation' and prohibiting different packaging or 'variants' for cigarettes sold under a given brand, as well as a Decree imposing an increase in the size of the health warnings on the surface of the cigarette packages from 50 per cent to 80 per cent, leaving only 20 per cent of the cigarette pack for trademarks, logos and other information. These cases stand out as they rank among the very few investor-State arbitration cases that have ever been

10 WHO, 'Plain Packaging of Tobacco Products: Evidence, Design and Implementation' (2016) $3-19$.

11 See Tobacco Plain Packaging Act 2011 (Cth) (Austl) and Tobacco Plain Packaging Regulations 2011 (Cth) (Austl) <https://www.health.gov.au/health-topics/smoking-and-tobacco/ tobacco-control/tobacco-plain-packaging $>$.

12 See Cancer Council, 'Timeline, International Developments \& Major News Stories'<https:// www.cancervic.org.au/plainfacts/timelineandinternationaldevelopments>.

13 Tobacco Tactics, 'Industry Arguments Against Plain Packaging' < https://tobaccotactics.org/ wiki/industry-arguments-against-plain-packaging $>$.

14 Philip Morris was also involved in domestic proceedings, as intervener (alongside Imperial Tobacco) in support of the plaintiffs (British American Tobacco and Japan Tobacco International) in Australian proceedings and as plaintiff in its own right in Uruguay: see respectively British American Tobacco Australasia Limited \& Ors v Commonwealth of Australia [2012] HCA 30 (Austl) <https://www.hcourt.gov.au/cases/case-s409/2011>; Philip Morris Brands Sàrl, Philip Morris Products SA and Abal Hermanos SA v Oriental Republic of Uruguay, ICSID Case No ARB/10/7, Award (8 July 2016) (Philip Morris v Uruguay) paras 154-167 (British American Tobacco separately challenged the tobacco control measures). 
instigated against legislation (as opposed to single instances of implementation or administrative acts). ${ }^{15}$ Both cases were, however, roundly rejected by the respective investor-State tribunals - albeit on different grounds.

Philip Morris v Australia concerned a dispute brought by Philip Morris Asia Limited (the regional headquarters of Philip Morris International) under the Hong Kong-Australia Bilateral Investment Treaty (BIT) (1993) against Australia on the basis of the latter's enactment and enforcement of the Tobacco Plain Packaging Act (2011). Philip Morris claimed that the legislation violated intellectual property rights relating to tobacco products and packaging, resulting in an indirect expropriation which had the effect of substantially diminishing the value of its investments in Australia. More specifically, the Claimant argued that the Act was in breach of the prohibition on expropriation and the obligation to provide fair and equitable treatment (FET). ${ }^{16}$ The Tribunal did not examine the merits of this argument, because it deemed the claim inadmissible: the commencement of proceedings was viewed as an abuse of process because the corporate restructuring of Philip Morris Asia had occurred when there was already a reasonable prospect that the dispute would materialise. ${ }^{17}$ In other words, the Tribunal considered that the investor had changed its corporate structure for the very purpose of starting investment arbitration proceedings. As a result, the claim failed at this jurisdiction hurdle.

The Philip Morris $v$ Uruguay case was initiated by Philip Morris Brand Sàrl (PMB) (the Swiss subsidiary of Philip Morris International) and two affiliates under the Switzerland-Uruguay BIT (1991) on the basis of Uruguay's treatment of the trademarks of its cigarette brands. Two of the host State's measures were contested: its Single Presentation Requirement (SPR), which permitted only one variant of cigarette per brand, and its 80/80 Regulation, which increased the size of graphic health warnings on cigarette packages to 80 per cent (front and back). ${ }^{18}$ Again, the Claimants argued that the host State's measures violated both the expropriation and FET standards. ${ }^{19}$ In addition, the Claimants alleged that their rights to use and enjoy their

15 Less than 10 per cent of cases are initiated against legislation. See T Thakur, 'Reforming the Investor-State Dispute Settlement Mechanism and the Host State's Right to Regulate: A Critical Assessment' (2021) 59 IJIl L 59, 173, 184 fn 59; C Tietje and F Baetens, 'The Impact of Investor-State-Dispute Settlement (ISDS) in the Transatlantic Trade and Investment Partnership: Study prepared for Minister for Foreign Trade and Development Cooperation, Ministry of Foreign Affairs, The Netherlands' (24 June 2014) para 87 <https://www.eumonitor.eu/9353000/1/ j4nvgs5kjg27kof_j9vvik7m1c3gyxp/vjn8exgvufya/f=/blg378683.pdf $>$.

16 See Agreement between the Government of Australia and the Government of Hong Kong for the Promotion and Protection of Investments (adopted 15 September 1993, entered into force 15 October 1993) 1770 UNTS 385 arts 2, 6.

17 Philip Morris Asia Limited v Commonwealth of Australia, PCA Case No 2012-12, Award on Jurisdiction and Admissibility (17 December 2015) (Philip Morris v Australia) paras 586-588.

18 Philip Morris v Uruguay (n 14).

19 See Agreement between the Swiss Confederation and the Oriental Republic of Uruguay for the Reciprocal Promotion and Protection of Investments (adopted 7 October 1988, entered into force 22 April 1991) 1976 UNTS 389 arts 3(2), 5. 
investments had been impaired and that the host State had failed to observe its commitments concerning the use of trademarks and had committed a denial of justice. ${ }^{20}$

The Tribunal dismissed the claim, holding that indirect expropriation does not occur 'as long as sufficient value remains after the Challenged Measures are implemented', while a partial loss does not constitute expropriation. ${ }^{21}$ Moreover, the Tribunal offered an additional reason for dismissing the claim of indirect expropriation, namely that the challenged measures were 'a valid exercise of the State's police powers' with the consequence of defeating the claim for expropriation under Article 5(1) of the BIT. ${ }^{22}$ The Tribunal integrated the police powers doctrine as a relevant rule of general international law in its interpretation of the BIT, but also relied on Uruguay's obligations under the FCTC - 'guaranteeing the human rights to health'-and the WHO's amicus curiae brief in determining that the impugned measures were potentially an effective means of protecting public health and thus a reasonable exercise of regulatory power. ${ }^{23}$ Concerning the FET claim, a majority of the Tribunal found there had been no breach of the Claimants' 'legitimate expectations' nor of the 'stability of the legal framework'. ${ }^{24}$ Again, the majority placed weight on Uruguay's pursuit of its obligations under the FCTC and the evidence submitted by the WHO in concluding that the measures were not arbitrary. ${ }^{25}$ The majority also agreed with the Respondent that the 'margin of appreciation' is not limited to the context of the European Convention of Human Rights (ECHR) but 'applies equally to claims arising under BITs', at least in contexts such as public health. ${ }^{26}$

In relation to the SPR, the Tribunal held that what mattered was not the effect of the measure but whether it was a 'reasonable' measure when it was adopted, that it was not disproportionate and that it was adopted in good faith. ${ }^{27}$ It decided that the SPR was indeed a reasonable measure, not arbitrary, grossly unfair, unjust, discriminatory or disproportionate, and that this was especially so considering its relatively minor impact on the Claimants' business. ${ }^{28}$ The Tribunal found that substantial deference was due to governments in this regard, as '[s]ome limit had to be set, and the balance to be struck between conflicting considerations was very largely a matter for the government' ${ }^{29}$

20 ibid arts 3, 3(1), 11.

21 Philip Morris v Uruguay (n 14) para 286.

22 ibid para 287.

23 ibid paras 290-307. See further CE Foster, 'Respecting Regulatory Measures: Arbitral Method and Reasoning in the Philip Morris v Uruguay Tobacco Plain Packaging Case' (2017) 26 Review of European, Comparative \& International Environmental Law 287.

24 Philip Morris v Uruguay (n 14) paras $421 \mathrm{ff}$.

25 ibid paras 390-396.

26 ibid para 399. For a strong dissent on this point, see Philip Morris Brands Sàrl, Philip Morris Products SA and Abal Hermanos SA v Oriental Republic of Uruguay, ICSID Case No ARB/10/7, Concurring and Dissenting Opinion of Gary Born (28 June 2016) paras 181-191. The partially dissenting arbitrator has further developed his argument with co-authors: G Born, D Morris and S Forrest, "A Margin of Appreciation": Appreciating Its Irrelevance in International Law" (2020) 61 HarvIntLJ 70. 27 Philip Morris v Uruguay (n 14) para 409.28 ibid para 410.

29 ibid para 418 . 
The question was whether the 80 per cent limit was 'entirely lacking in justification or wholly disproportionate' - and the Tribunal decided it was not. ${ }^{30}$ As a result, the $80 / 80$ Regulation was found to be a reasonable measure adopted in good faith. ${ }^{31}$

In sum, two investor-State tribunals, populated by different arbitrators, operating independently of each other and under different BITs, reached the same outcome (a win for the respective host States) albeit on different grounds: either because the Claimants had committed an abuse of process in bringing the claim (Philip Morris v Australia) or because public health considerations prevailed on the merits (Philip Morris v Uruguay). ${ }^{32}$ As an additional win for Uruguay, the latter Tribunal even awarded the Respondent 7 million USD to cover the costs of its defence.

The tobacco industry also fought the point in different fora, supporting Honduras, the Dominican Republic, Cuba and Indonesia in bringing cases before the WTO Dispute Settlement Body against Australia, ${ }^{33}$ alleging that its plain packaging rules violated the Technical Barriers to Trade (TBT) Agreement, the Agreement on Trade-Related Aspects of Intellectual Property Rights (TRIPs) and the General Agreement on Tariffs and Trade (GATT) but again a panel found that no violation had been committed. ${ }^{34}$ These findings were upheld on appeal. ${ }^{35}$ Together, the trade and investment jurisprudence suggests that regulatory caution in respect of the tobacco

30 ibid para 419.

31 ibid para 420.

32 In two earlier investment arbitrations in the tobacco industry, Feldman v Mexico and Grand River $v$ USA, the Tribunals did not touch upon public health considerations. In Feldman, the Tribunal held that the tax scheme introduced by Mexico was merely a rational public policy having the objective to prevent an unlawful export of cigarettes: Feldman v Mexico, ICSID Case No ARB(AF)/99/1, Award (16 December 2002) para 136. In Grand River, several claims did not make it through the jurisdictional phase. Those considered on the merits were dismissed due to the status of the indigenous claimants: Grand River Enterprises Six Nations Ltd and Ors $v$ United States of America, ICSID Case No ARB/10/5, Award (12 January 2011) paras 218-219. Hence, these cases are of little guidance when assessing the potential tension between trademarks and public health.

33 Proceedings were also initiated by Ukraine, but discontinued: Note by the Secretariat, Australia-Certain Measures Concerning Trademarks, Geographical Indications and Other Plain Packaging Requirements Applicable to Tobacco Products and Packaging, WT/DS/434/17, 30 June 2016 (noting the lapse of authority for the establishment of the panel following the request of Ukraine).

34 Panel Report, Australia-Certain Measures Concerning Trademarks, Geographical Indications and Other Plain Packaging Requirements Applicable to Tobacco Products and Packaging, WT/DS435/R, WT/DS441/R, WT/DS458/R, WT/DS467/R, adopted 27 August 2018 (Australia-Tobacco Plain Packaging). For further analysis, see M Davison and P Emerton, 'The Treatment of Public Health Measures Affecting Intellectual Property under Multilateral and Plurilateral Trade and Investment Agreements' (2019) 20 Journal of World Investment and Trade 759; E Sheargold and AD Mitchell, 'Public Health in International Investment Law and Arbitration' in J Chaisse, L Choukroune and S Jusoh (eds), Handbook of International Investment Law and Policy (Springer 2019); P Ranjan and P Anand, "How "Healthy" are the Investment Treaties of South Asian Countries: An Empirical Study of Public Health Provisions in South Asian Countries' BITs and FTA Investment Chapters' (2018) 33 ICSIDRev 406.

35 Appellate Body Report, Australia-Certain Measures Concerning Trademarks, Geographical Indications and Other Plain Packaging Requirements Applicable to Tobacco Products and Packaging, WT/DS435/AB/R, WT/DS 441/AB/R, adopted 29 June 2020. 
industry may at least be partly driven by domestic decision-makers' lack of appreciation of how seriously international trade and investment adjudicators take the protection of public health. ${ }^{36}$

\section{B. Access to Medicine}

A second category of cases where investment protection and public health interact also relates to intellectual property, but this time involves issues relating to patent protection, which may clash with access to medicine and health care. One of the earliest cases on record is Signa $v$ Canada, where a notice of intent was registered in March 1996 when a manufacturer of generic pharmaceutical products sought to challenge the duration of patents. ${ }^{37}$ The investor claimed that a longer duration frustrated the legitimate expectations of Article 1105 of NAFTA, but the case soon settled for confidential reasons. ${ }^{38}$

A case concerning the regulation of health insurance, Achmea $v$ Slovak Republic, was initiated under the Dutch-Slovak BIT in 2008. It dealt with regulatory measures which included a ban on profits and transfers that allegedly constituted a 'systematic reversal of the 2004 liberalisation of the Slovak health insurance market'. ${ }^{39}$ The investor (a Dutch insurer) had relied upon this liberalisation and its reversal arguably destroyed the value of its investment, which could neither generate profits nor be sold. Allegedly, this resulted in, inter alia, an indirect expropriation and a breach of the FET standard. ${ }^{40}$ The Claimant argued that, as the Slovak Constitutional Court had found in 2011 that the 'ban on profits' was unconstitutional, this 'effectively established a breach of the BIT', and so compensation was due for the period in which the ban was in force. ${ }^{41}$ The Respondent argued that its accession to the EU in May 2004 terminated the BIT or, at least, rendered its arbitration clause inapplicable. The Tribunal chose to follow the argument of the Claimant and

\footnotetext{
36 cf C Moehlecke, 'The Chilling Effect of International Investment Disputes: Limited Challenges to State Sovereignty' (2020) 64 International Studies Quarterly 1.

37 Signa SA de CV v Government of Canada (Notice of Intent to Submit a Claim to Arbitration under Section B of Chapter 11 of the North American Free Trade Agreement, 4 March 1996).

38 It has been suggested that withdrawal of this case was 'due to inception of the TRIPS Agreement', which extended patent protection to 20 years: V Vadi, 'Access to Essential Medicines \& International Investment Law: The Road Ahead' (2007) Journal of World Investment and Trade 505, 525. But Signa's Notice of Intent was filed after the TRIPS Agreement came into force on 1 January 1995 and related amendments to Canadian intellectual property law on 1 January 1996: L-P Gravelle, 'TRIPS and Its Impact on Canadian Intellectual Property Legislation' (Robic 1996) 2.

39 Achmea BV v Slovak Republic, PCA Case No 2008-13, Award on Jurisdiction, Arbitrability and Suspension (26 October 2010) (Achmea v Slovak Republic) para 7.

40 See Agreement on the Encouragement and Reciprocal Protection of Investments between the Kingdom of the Netherlands and the Czech and Slovak Republic (adopted 29 April 1991, entered into force 1 October 1992) 2242 UNTS 205 arts 3(1), 5.

41 Achmea $v$ Slovak Republic (n 39) para 206.
} 
ordered the Slovak Republic to pay EUR 22.1 million in damages. ${ }^{42}$ However, the case should be considered less a 'victory' for investment protection over public health considerations, and more a preference for one health insurance regulation over another within the context of a conflict between EU and international law and jurisdiction.

The third case is Apotex $v$ USA, which concerned pharmaceutical imports and sales under NAFTA and the US-Jamaica BIT. ${ }^{43}$ In 2009, the US Food and Drug Administration (FDA) had placed Apotex's Etobicoke and Signet facilities on 'Import Alert' in the aftermath of a failed inspection. The FDA signalled that since the drugs from those facilities were adulterated the products could be detained at the US border without physical examination. ${ }^{44}$ As a result, Apotex's US business was decimated, with 80 per cent of its supplies cut off from Canada, causing losses of over USD 500 million. Subsequently, Apotex recalled the adulterated drug products from the US market, hired third-party consultants to help bring its facilities into compliance with US law and promised to overhaul its operations, management structure, and quality control systems. In 2011, the FDA decided to lift the Import Alert. ${ }^{45}$ The Claimants asserted that the US had violated its most-favoured-nation and national treatment obligations (because allegedly, no US investor or investment had ever been subjected to a measure as severe as the Import Alert imposed on the Apotex companies) as well as the FET standard. ${ }^{46}$ The Tribunal dismissed the case on the merits because it did not consider Apotex 'in like circumstances' as the domestic comparators, without basing any of its reasoning on public health policy. ${ }^{47}$

The fourth case is Melvin Howard v Canada, which concerned medical (surgical) services and the planned construction of a private healthcare facility. A range of legislative and administrative measures allegedly impeded the completion of the project, causing 'numerous set-backs' through zoning requirements and other legal hurdles. ${ }^{48}$ The Claimants allegedly suffered 'a major loss' because the Respondent's actions caused their medical

42 Subsequently, the CJEU ruled that the investor-State arbitration clause in the NetherlandsSlovakia BIT was incompatible with EU law because the effectiveness of EU law may be undermined if it is applied by bodies such as investor-State tribunals that operate outside the EU jurisdiction. The German Federal Supreme Court set aside the award, see Case C-284/16 Slovak Republic $v$ Achmea BV EU:C:2018:158 (Slovak Republic $v$ Achmea) paras 56-58 and Bundesgerichtshof [BGH] [Federal Court of Justice] Oct 31, 2018, I ZB 2/15 (Ger).

${ }_{43}$ Apotex Holdings Inc and Apotex Inc $v$ United States of America, ICSID Case No ARB(AF)/ 12/1, Award (25 August 2014) (Apotex v USA) paras 2.30ff. 44 ibid para 2.15.

45 ibid para 2.48 .

46 North American Free Trade Agreement (adopted 12 December 1992, entered into force 1 January 1994) (1993) 32 ILM 289 (NAFTA) arts 1102, 1103 and 1105; Treaty Between the United States of America and Jamaica Concerning the Reciprocal Encouragement and Protection of Investment (adopted 4 February 1994, entered into force 7 March 1997) TIAS 97-307 art II(2) (b) and (6).

47 Apotex v USA (n 43) paras 8.51, 8.78, 9.72.

${ }_{48}$ Melvin J Howard, Centurion Health Corporation and Howard Family Trust $v$ The Government of Canada, PCA Case No 2009-21, Notice of Arbitration (5 January 2009) paras $33 \mathrm{ff}$. 
technology to be shipped back to the US, in breach of the Canada's obligations in relation to expropriation, most-favoured-nation and national treatment, the minimum standard of treatment and FET. ${ }^{49}$ Before the proceedings on jurisdiction and merits had started, however, the case was terminated because the Claimants failed to pay the deposit. ${ }^{50}$

Fifth, in Les Laboratoires Servier v Poland, a drug manufacturer initiated arbitral proceedings against Poland in a dispute concerning the revocation of marketing authorisation of medicines. Rejecting Poland's argument that the revocation was justified under the police powers doctrine, the Tribunal held that the revocation constituted an indirect expropriation and was disproportionate, discriminatory and 'not a matter of public necessity'. ${ }^{51}$ As the publicly available arbitral award is heavily redacted, the exact role, if any, of public health in the discussion is unclear. Significantly, the Tribunal found that the burden 'falls onto the Claimants to show that Poland's regulatory actions were inconsistent with a legitimate exercise of Poland's police powers. If the Claimants produce sufficient evidence for such a showing, the burden shifts to Poland to rebut it. ${ }^{52}$

The claims in the sixth case, Eli Lilly $v$ Canada, arose from the invalidation of the Claimant's Canadian patents protecting the drugs marketed in Canada as Strattera and Zyprexa. ${ }^{53}$ The domestic courts had invalidated these patents on the ground that they did not meet the requirement that an invention be 'useful', in accordance with the so-called 'promise utility doctrine'. ${ }^{54}$ The Claimant asserted that, by adopting this doctrine, the Canadian courts had dramatically altered the application of the relevant provision in the Patent Act, which it considered to be inconsistent with Canada's obligations related to patent protection under NAFTA, and more precisely the prohibition on expropriation and the FET standard. ${ }^{55}$ The Tribunal found, however, that

49 NAFTA (n 46) arts 1102, 1103, 1105, 1110.

50 The Claimants had requested that the President of the World Bank designate an appointing authority to decide on their challenge to Mr Henri Alvarez's appointment as arbitrator. The Claimants argued that it would be improper for the ICSID Deputy Secretary-General himself to rule on the admissibility of their request to the World Bank President because of a conflict of interest and, in the meantime, refused to pay the deposit. The Tribunal referred to the ICSID Convention (arts 60-63) and terminated proceedings. See Melvin J Howard, Centurion Health Corporation and Howard Family Trust v The Government of Canada, PCA Case No 2009-21, Order for the Termination of the Proceedings and Award on Costs (2 August 2010) paras 23, 28, $35,42,64$.

51 Les Laboratoires Servier, SAS, Biofarma, SAS and Arts et Techniques du Progres SAS v Republic of Poland, UNCITRAL, Final Award (14 February 2012) para 575.

52 ibid para 584 .

53 Eli Lilly and Company v Government of Canada, ICSID Case No UNCT/14/2, Final Award (16 March 2017) (Eli Lilly v Canada).

54 ibid paras 5, 80-84, referring to, inter alia, Eli Lilly Canada Inc v Novopharm Limited, 2011 FC 1288 (Can) and Eli Lilly Canada Inc, et al v Novopharm Limited, 2013 CanLII 26762 (SCC, Can). See also Eli Lilly and Company v Government of Canada, ICSID Case No UNCT/14/2, Notice of Intent to Submit a Claim to Arbitration Under NAFTA Chapter Eleven (7 November 2012) paras 99-104.

55 See NAFTA (n 46) arts $1105,1110$. 
such 'dramatic transformation of the utility requirement in Canadian law' was not supported by the facts, ${ }^{56}$ nor by a comparative analysis with other jurisdictions. ${ }^{57}$ It concluded that the Claimant had not met its burden of proving a violation of legitimate expectations. ${ }^{58}$ The other claims alleging the arbitrary and discriminatory character of the utility requirement were equally dismissed. ${ }^{59}$

In sum, these cases illustrate the range of techniques available to investment tribunals in reconciling ostensible conflicts between the economic and public health interests. In Signa $v$ Canada, the Claimant was a manufacturer of generic medicine who argued that the duration of patents should be more limited than was provided for in Canadian law. More limited patent duration is one of the main demands of those who advocate wider access to medicines and who would thus have found themselves on the side of the investor in this case. ${ }^{60}$ The Achmea award arguably dealt with a clearer conflict between investment and public health, assuming that the measures requiring the Claimant to reinvest its profits would have yielded benefits to Slovak healthcare rather than disincentivising new investment. However, the dispute ultimately turned on a jurisdictional conflict between EU and international law. Equally, in Apotex, the choice was not between investment protection or access to medicine, but rather whether a case that was essentially a trade dispute (concerning medical drugs import) could be brought under an investment agreement.

In Melvin Howard and Eli Lilly, if anything, the investors were advocating in favour of increased access to medicine: in the former, for the sale of medical services and the construction of a healthcare facility; in the latter, for the patenting of new drugs. Some argue that the existence of a patent as such restricts access to medicine (and any IIA protecting patents as investments would therefore also restrict access), ${ }^{61}$ but if so, the problem lies not with investment law, but rather with the global and domestic protection of intellectual property rights. ${ }^{62}$ As the Melvin Howard case was terminated before any written submissions on behalf of the Canadian government had

56 Eli Lilly v Canada (n 53) paras 351, 366, 376. $\quad 57$ ibid para 379. $\quad 58$ ibid para 385.

59 For further analysis, see Sheargold and Mitchell (n 34); V Vadi, 'Towards a New Dialectics: Pharmaceutical Patents, Public Health and Foreign Direct Investments' (2015) 5 NYU Journal of Intellectual Property \& Entertainment Law 113, $160 \mathrm{ff}$.

60 See WHO, 'Advancing the Right to Health: The Vital Role of Law' (2016) 235-41 (discussing compulsory licensing under Article 31 of the TRIPS Agreement) < https://apps. who. int/iris/bitstream/handle/10665/252815/9789241511384-eng.pdf $>$.

61 See BN Sampat, 'Academic Patents and Access to Medicines in Developing Countries' (2009) 99(1) American Journal of Public Health 9; A Attaran, 'How Do Patents and Economic Policies Affect Access to Essential Medicines in Developing Countries?' (2004) 23 Health Affairs 155; 'Intellectual Property Protection: Impact on Public Health' (2005) 19 WHO Drug Information Bulletin 236.

${ }^{62}$ See calls within the WTO (and beyond) for a waiver of patent protection for COVID-19 vaccines: eg Editorial, 'A Patent Waiver on COVID Vaccines is Right and Fair' (2021) 593 Nature 478 . 
been made, it is impossible to say whether the government would have sought to defend its actions on public health grounds. In order to defend itself in Eli Lilly, the Canadian government chiefly relied on procedural grounds (eg lack of jurisdiction ratione temporis) and on the argument that there had been no dramatic change in Canadian courts' interpretation of the requirement under domestic patent law that an invention be 'useful'. In other words, the Canadian government focused on a legal-technical defence, rather than invoking substantive arguments based on public health - and was successful. What is important, however, is that this case law analysis shows that tribunals have consistently aimed to interpret investment law in ways which avoid, minimise or eliminate potential conflicts between the economic interests of the healthcare industry and access to medicine.

\section{Environment-Related Health Measures}

A third and final category of cases where the protection of investments and public health could potentially clash are disputes involving environmentrelated health measures (for example relating to landfills, food safety and water distribution) which could be perceived as impinging upon economic interests. ${ }^{63}$ One of the earliest cases in which this potential clash resulted in an investor-State dispute was Ethyl $v$ Canada, which concerned a Canadian ban on inter-provincial trade of the fuel additive methylcyclopentadienyl manganese tricarbonyl (MMT), which Canada argued was a highly toxic substance that could cause neurological defects and other public health risks. ${ }^{64}$ As this case was settled between the parties, it is impossible to know how a tribunal would have weighed the diverging interests at stake.

Secondly, the Claimant initiated the Tecmed $v$ Mexico case on the grounds that municipal, state and federal actions, including the decision by the Environmental Protection Agency to deny renewal of the Landfill Permit and order its closure, violated Mexico's obligations under the Spain-Mexico BIT. The Tribunal considered it significant that the 'violations [of which the investor had been accused by the government] did not compromise the condition of the environment, the ecological balance or the health of the population'. ${ }^{65}$ As a result, the Tribunal concluded that the Respondent's actions were driven by 'sociopolitical concerns' because none of the actors involved had expressed any concerns that there was a 'danger that the Landfill may pose to public health, ecological balance or the environment'. ${ }^{66}$ Had such a danger been

63 For a broader overview of environment-related investment disputes, see JE Viñuales, 'Foreign Investment and the Environment in International Law: Current Trends' in K Miles (ed), Research Handbook on Environment and Investment Law (Edward Elgar 2019).

${ }^{64}$ Ethyl Corporation $v$ The Government of Canada, UNCITRAL, Award on Jurisdiction (24 June 1998). See also Sheargold and Mitchell (n 34) 8.

65 Técnicas Medioambientales Tecmed, SA v The United Mexican States, ICSID Case No ARB (AF)/00/2, Award (29 May 2003) para 124 ( Tecmed $v$ Mexico).

66 ibid para 129. 
demonstrably present, the Tribunal may not have held that Mexico had expropriated Tecmed's investment and violated the FET standard.

Thirdly, the investment in $A W G v$ Argentina consisted of a shareholding in a local company that held a concession for water distribution and wastewater treatment services in Buenos Aires and surrounding municipalities. ${ }^{67}$ Faced with claims regarding its alleged failure or refusal to apply previously agreed adjustments to the tariff calculation and adjustment mechanisms, Argentina invoked a necessity defence under customary international law. At this point, the Tribunal recognised that ' $[\mathrm{t}]$ he provision of water and sewage services to the metropolitan area of Buenos Aires certainly was vital to the health and well-being of nearly ten million people and was therefore an essential interest of the Argentine State'. ${ }^{68}$ The defence nevertheless failed as the Tribunal established that Argentina could have satisfied its essential interest through alternative measures.

Fourthly, the first seminal case to go into the merits of the discussion on environment-related health measures was Chemtura $v$ Canada. ${ }^{69}$ Here, the investor claimed that a ban on 'lindane', a pesticide used in farming which allegedly had negative effects on human health, formed an indirect expropriation under Article 1110 of NAFTA. The Tribunal found, inter alia, that, even if the ban had caused a substantial deprivation of the Claimant's investment, 'there was still no expropriation because the [government's] decision to phase out all agricultural applications of lindane was a valid exercise of Canada's police powers to protect public health and the environment' ${ }^{70}$ Foreshadowing the approach in Philip Morris $v$ Uruguay, the Tribunal accepted that a 'margin of appreciation' is relevant to its assessment of the FET standard, but that an investigation of how 'certain agencies manage highly specialized domains involving scientific and public policy determinations' must be conducted 'in concreto when assessing the specific measures'. ${ }^{71}$ Moreover, and akin to Uruguay's pursuit of its obligations under the FCTC, the Tribunal in Chemtura found that Canada's review of lindane was undertaken in good faith as a result of its obligations under multilateral environmental agreements. ${ }^{72}$

A fifth relevant case was Gallo $v$ Canada, ${ }^{73}$ which dealt with water contamination due to mine waste disposal. The US investor argued that Canada had violated Articles 1105 (FET) and 1110 (expropriation) of NAFTA when it enacted the Adams Mine Lake Act which prohibited waste disposal at the Adams Mine site, revoked environmental and operational permits, retroactively banned certain agreements and retroactively extinguished the investor's causes of action under Canadian law. Again, it is

67 Suez, Sociedad General de Aguas de Barcelona SA, and Vivendi Universal SA v The Argentine Republic, ICSID Case No ARB/03/19, and AWG Group v The Argentine Republic, UNCITRAL, Decision on Liability (30 July 2010). 68 ibid para 260.

${ }^{69}$ Chemtura Corporation v Government of Canada, UNCITRAL, Award (2 August 2010).

70 ibid para $254 . \quad 71$ ibid para 123 . 72 ibid paras 135-143.

73 Vito G Gallo v The Government of Canada, UNCITRAL, Award (15 September 2011). 
impossible to know how the Tribunal would have assessed the public health versus economic interests, because the case was decided in favour of Canada on jurisdictional grounds. ${ }^{74}$

Sixth, in Roussalis v Romania, the claims arose out of disagreements between the investor and the host State relating to the purchase of shares in a large frozen food warehousing facility, tax liabilities and penalties imposed on the investor, and the enforced closure of its operation due to the alleged failure to comply with EUmandated food safety regulations. ${ }^{75}$ Regarding the latter, the Tribunal was clear: the Respondent's regulatory measures 'were justified by an important public safety purpose, namely, serious public health and safety considerations' ${ }^{76}$ indeed:

... food and safety policies are commonplace in many countries and promote an important public safety purpose, namely public health. Each of the State authorities' decisions was motivated in regard to these food and safety regulations. The Tribunal is therefore not convinced at all that the control actions and the subsequent decisions of the tax authorities were aimed at blocking the activity of the company. ${ }^{77}$

A seventh, atypical, case-Allard $v$ Barbados - saw an investor relying on environmental health grounds in order to hold the government of Barbados accountable for a raw sewage spill which had contaminated a nature sanctuary. ${ }^{78}$ The State had failed to repair a sluice gate, neglected to reduce the run-off of contaminants into the sanctuary and omitted to enforce its own Marine Pollution Control Act. The dispute concerned whether this conduct had caused such degradation to the environment at the sanctuary as to render its operation as an ecotourism attraction impossible or financially unsustainable, justifying closure. The Tribunal found that because 'Mr. Allard remain[ed] the owner of the Sanctuary grounds, on which he continue[d] to operate a café [...], [i]t is therefore undisputed that the Claimant has not been deprived of his entire investment in Barbados' ${ }^{79}$ The investor had argued that what had been expropriated was not so much the land itself, but rather his ability to run an eco-tourism business on this land. The Tribunal, however, concluded that even if it were to accept that the destruction of the environment could constitute indirect expropriation, the Claimant had failed to establish that he had closed his business due to the contamination. ${ }^{80}$

Finally, a similar type of investment as in $A W G$ was at issue in Urbaser $v$ Argentina, which concerned a minority shareholding in an Argentinean vehicle company that held a concession for the provision of drinking water

74 ibid para 336.

75 Spyridon Roussalis v Romania, ICSID Case No ARB/06/1, Award (7 December 2011).

76 ibid para $664 . \quad 77$ ibid para 686.

78 Peter A Allard v The Government of Barbados, PCA Case No 2012-06, Award (27 June 2016) (Allard v Barbados). See also J Paine, 'Failure to Take Reasonable Environmental Measures as a Breach of Investment Treaty?' (2017) 18 Journal of World Investment and Trade 745.

79 Allard $v$ Barbados (n 78) para 264.

80 ibid para 265. 
supply and sewerage services in Buenos Aires. ${ }^{81}$ The investors alleged that Argentina had unlawfully interfered with the tariff regime applicable to the investment and violated various provisions of the concession agreement through the enactment of emergency measures during the 2001-02 financial crisis. The Tribunal confirmed the importance of public health considerations, highlighting the State's prerogatives in terms of 'protecting public health'. ${ }^{82}$ However, since public health considerations did not play a crucial role in the parties' arguments in the dispute, the Tribunal did not elaborate further. ${ }^{83}$

Other investment arbitrations concerning environmental issues include Methanex $v$ USA and SD Myers $v$ Canada, in which the respective tribunals had to decide on the lawfulness of a ban on methyl tertiary butyl ether (MTBE) due to concerns regarding groundwater contamination and polychlorinated biphenyls (PCBs) exportation. In the former case, the Tribunal held that the ban constituted a bona fide policy to protect not only the environment but also general public health. ${ }^{84}$ The SD Myers Tribunal dismissed Canada's claim that the export ban was aimed at protecting the environment and found that it mainly shielded the Canadian PCB disposal industry from competition. ${ }^{85}$

In sum, when faced with a clash between environment-related measures to protect public health and economic interests, some cases have been settled by the parties before an award was issued $(E t h y l)$ or were won by the host State on jurisdictional grounds (Gallo). Where the tribunals did go into the merits of the issue (Chemtura, Roussalis and $A W G$ ), they have held that the State's police powers in protecting public health prevailed, provided that good governance standards (such as due process, science-based decision-making, nondiscrimination, necessity, proportionality and good faith) were respected. Tribunals have determined these good governance standards by reference to a State's pursuit of its international health or environmental obligations (Chemtura). Where public health or environmental grounds were considered to be absent or largely unfounded (Tecmed and, indirectly, Urbaser), the actions of the States were subject to closer scrutiny. Finally, Allard was an atypical case as it related to protection of the environment (at least, from a 'polluter pays' perspective) in which the polluter in question was not the investor but the State-a reversal of the usual roles. ${ }^{86}$ The Tribunal, however,

81 Urbaser SA and Consorcio de Aguas Bilbao Bizkaia, Bilbao Biskaia Ur Partzuergoa v The Argentine Republic, ICSID Case No ARB/07/26, Award (8 December 2016).

82 ibid para 80.

${ }^{83}$ For a summary of the dispute, see Urbaser SA and Consorcio de Aguas Bilbao Bizkaia, Bilbao Biskaia Ur Partzuergoa v The Argentine Republic, ICSID Case No ARB/07/26 (2020) 18 ICSID Rep 554 (G Álvarez Ávila and R Mier y Teran Ruesga).

${ }^{84}$ Methanex Corporation $v$ United States of America, UNCITRAL, Final Award of the Tribunal on Jurisdiction and Merits (3 August 2005) Pt III, Ch A, paras 101-102.

${ }_{85}$ SD Myers, Inc v Government of Canada, UNCITRAL, First Partial Award (13 November 2000) para 194.

86 Unlike other principles, such as prevention, the polluter pays principle does not 'hold the state directly responsible for the pollution caused by a corporation or industry': P Schwartz, 'Principle 16' 
applied a rather strict causation test, focusing on whether the environmental damage had directly caused the closure of the sanctuary (as the polluted grounds could still be used for purposes other than eco-tourism), so the investor lost.

\section{Interim Conclusion}

The Table below summarises the 18 investment disputes surveyed above, highlighting the phase at which the dispute was resolved and on what basis. The State prevailed in 10 out of the 18 cases, two were settled, and the investor prevailed in six.

The foregoing survey of the case law does not suggest that tribunals overwhelmingly sided with the claimants in any of the areas addressed. Rather, by and large, they seem to have taken public health into consideration when it was invoked and frequently accepted it as an important policy objective of host States. The widespread perception of investment treaties as riding roughshod over health concerns therefore finds little support in a careful appraisal of how such treaties have been interpreted and applied by past tribunals. Moreover, some well-known dissenting opinions demonstrate arbitrators' increased sensitivity to the wider legitimacy crisis faced by international investment law, ${ }^{87}$ especially in cases concerning environmental issues. ${ }^{88}$ Preliminary empirical work suggests, however, that arbitrators are generally more responsive to the preferences of influential States than the diffuse signals of public opinion (the latter rather influences States' future treaty-making activities). ${ }^{89}$

The significant criticism attracted by the Philip Morris cases, for instance, was translated into investment treaty policy by a large bloc of States through

in JE Viñuales (ed), The Rio Declaration on Environment and Development: A Commentary (Oxford University Press 2015) 447.

${ }^{87}$ K Polonskaya, 'Arbitral Institutions' Response to Perceived Legitimacy Deficits: Promoting Diversity, Transparency and Expedition in Investor-State Arbitration' in F Baetens, Legitimacy of Unseen Actors in International Adjudication (Cambridge University Press 2019); E Sardinha, 'Party-Appointed Arbitrators No More : The EU-Led Investment Tribunal System' (2018) 17 LPICT 117; J Pauwelyn, 'Who Decides Matters: the Legitimacy Capital of WTO Adjudicators versus ICSID Arbitrators' in N Grossman et al., Legitimacy and International Courts (Cambridge University Press 2018).

${ }^{88}$ See eg Bilcon of Delware Inc and others $v$ Government of Canada, PCA Case No 2009-04, Dissenting Opinion of Professor Donald McRae (10 March 2015) para 48 ('What the majority has done is add a further control over environmental review panels. ... This is a significant intrusion into domestic jurisdiction and will create a chill on the operation of environmental review panels.'); Eco Oro Minerals Corp v Republic of Colombia, ICSID Case No ARB/16/41, Partial Dissent of Professor Philippe Sands QC (9 September 2021) para 33 ('In the age of climate change and significant loss of biological diversity, it is clear that society finds itself in a state of transition. The law - including international law - must take account of that state of transition, which gives rise to numerous uncertainties. Adjudicators - judges and arbitrators - recognise the need to proceed with caution at a time of transition and uncertainty.')

${ }^{89}$ See M Langford and D Behn, 'Managing Backlash: The Evolving Investment Treaty Arbitrator?' (2018) 29 EJIL 551. 
TAble.

Public health in investment disputes under existing treaties

\begin{tabular}{|c|c|c|c|c|c|c|}
\hline & Case & $\begin{array}{c}\text { Terminated } \\
\text { before decision }\end{array}$ & Jurisdiction & Admissibility & Merits & $\begin{array}{l}\text { Successful } \\
\text { party }\end{array}$ \\
\hline \multirow[t]{2}{*}{$\begin{array}{l}\text { Health warnings and } \\
\text { plain packaging }\end{array}$} & $\begin{array}{l}\text { Philip Morris v } \\
\text { Australia }\end{array}$ & & & $\begin{array}{l}\text { Abuse of } \\
\text { process }\end{array}$ & & State \\
\hline & $\begin{array}{l}\text { Philip Morris v } \\
\text { Uruguay }\end{array}$ & & & & $\begin{array}{l}\text { Police powers doctrine; } \\
\text { margin of appreciation }\end{array}$ & State \\
\hline \multirow[t]{6}{*}{ Access to medicine } & Signa $v$ Canada & Settled & & & & Unknown \\
\hline & $\begin{array}{l}\text { Achmea v Slovak } \\
\text { Republic }\end{array}$ & & & & Breach of FET & Investor \\
\hline & Apotex $v U S A$ & & & & $\begin{array}{l}\text { Not 'in like } \\
\text { circumstances', }\end{array}$ & State \\
\hline & $\begin{array}{l}\text { Melvin Howard v } \\
\text { Canada }\end{array}$ & $\begin{array}{l}\text { Claimant failed } \\
\text { to pay deposit }\end{array}$ & & & & State \\
\hline & $\begin{array}{l}\text { Les Laboratoires } \\
\text { Servier v Poland }\end{array}$ & & & & Expropriation & Investor \\
\hline & Eli Lilly v Canada & & & & $\begin{array}{l}\text { No violation of } \\
\text { legitimate expectations }\end{array}$ & State \\
\hline \multirow{4}{*}{$\begin{array}{l}\text { Environment-related } \\
\text { health measures }\end{array}$} & Ethyl v Canada & Settled & & & & Unknown \\
\hline & Tecmed v Mexico & & & & $\begin{array}{l}\text { Expropriation; breach of } \\
\text { FET }\end{array}$ & Investor \\
\hline & $A W G v$ Argentina & & & & Breach of FET & Investor \\
\hline & $\begin{array}{l}\text { Chemtura v } \\
\text { Canada }\end{array}$ & & & & $\begin{array}{l}\text { Police powers doctrine; } \\
\text { margin of appreciation }\end{array}$ & State \\
\hline
\end{tabular}


TABLE.

Continued 
the express option to deny the benefits of investment protection for tobacco control measures in the Trans-Pacific Partnership, the forerunner to Comprehensive and Progressive Agreement for Trans-Pacific Partnership (CPTPP). ${ }^{90}$ While tribunals adjudicating the Philip Morris disputes were doubtless aware of that development, their arbitral reasoning nevertheless relied on positive legal footholds to shore up their recognition of health policy, such as the FCTC and the confirmation of the police powers doctrine in recent treaties. ${ }^{91}$ However, an overreliance on less textually grounded techniques of treaty interpretation, such as the principle of systemic integration, would expose tribunals to the opposite criticism that they are eliding the restrictions on regulatory powers to which States have consented in order to attract foreign investment. ${ }^{92}$ In other words, the more legitimate and predictable avenue for States to signal their policy preferences and legal intentions to international tribunals is through precise and detailed treaty drafting, even if they seek simply to codify a balance between investment protection and public health that has been struck through adroit interpretation of older treaties. ${ }^{93}$

\section{PUBLIC HEALTH IN THE NEW GENERATION OF INVESTMENT TREATIES}

The 'first generation' of investment treaties (roughly, those concluded between 1959 and 2010) did not generally contain any reference to public health, or even human rights, or environmental protection more broadly. ${ }^{94}$ As a result, several investment tribunals have had to assess alleged violations of investment protection standards, which respondent States claimed were justified because of public health reasons, without any guidance from the treaty upon which their jurisdiction was founded. As discussed above, in nearly all of these cases, tribunals have nevertheless allowed public health reasons to prevail over investment interests.

90 Comprehensive and Progressive Agreement for Trans-Pacific Partnership (adopted 9 March 2018, entered into force 30 December 2018) [2018] ATS 23 (CPTPP). See S Puig and G Shaffer, 'A Breakthrough with the TPP: The Tobacco Carve-Out' (2016) 16 Yale Journal of Health Policy, Law and Ethics 327. See further section III. 2 below.

91 Philip Morris v Uruguay (n 14) paras 300 and 304.

92 P Ranjan, 'Police Powers, Indirect Expropriation in International Investment Law, and Article 31(3)(c) of the VCLT: A Critique of Philip Morris v. Uruguay’ (2019) 9 AsianJIL 98, 123.

93 Concerning the possible pitfalls in drawing strong inferences from State responses to investment case law (or lack thereof, due to budgetary and time constraints), see A Roberts, 'Power and Persuasion in Investment Treaty Interpretation: The Dual Role of States' (2010) 104 AJIL 179, 195-7.

94 As a rough illustration, 384 out of the 2986 BITs (12.9 per cent) signed between 1959 and 2010 contained a least one reference to the word 'health', as compared with 179 out of 303 BITs (59.1 per cent) signed between 2010 and 2021: see W Alschner, M Elsig and R Polanco, 'Introducing the Electronic Database of Investment Treaties (EDIT): The Genesis of a New Database and Its Use' (2021) 20 WorldTR 73. See also (n 3) above. 
Gradually realising that investment law does not operate in a vacuum, States have started to include references to human rights and the environment, or even to public health directly, in the 'new generation' of investment treaties and model BITs (IIAs and FTAs drafted after 2010). Some treaty instruments exclude measures concerning public health from the ambit of dispute settlement altogether. As an illustration, the CPTPP specifically refers to the adoption of measures concerning public health, as will be discussed below (sections 2-4), and does not allow investors to initiate proceedings concerning the legality of tobacco control measures. ${ }^{95}$ While this new generation of investment treaties does not depart radically from the manner in which the dual objectives of protecting foreign investment and public health have hitherto been reconciled in practice through treaty interpretation, by referring to general international law, and more technical defences, these treaties nevertheless represent a step toward greater legal certainty for States and investors alike.

\section{A. A Broad Spectrum of New Treaties}

Modern IIAs, including Model BITs, can be categorised based on whether and to what extent they incorporate references to public health, and they display a broad spectrum of treaty-drafting options. This spectrum runs from recent agreements that do not contain any mention of public health, such as the Nicaragua-Iran BIT (2019), to treaties that contain a comprehensive series of references to public health, such as the Norwegian Model BIT (2015). The latter includes no less than eight references to public health, together with a range of other public interest objectives: in its Preamble and its articles on national and most-favoured-nation treatment (Article 3), expropriation (Article 6), performance requirements (Article 8), prohibition on the lowering of standards (Article 11), right to regulate (Article 12), and the Joint Committee (Article 23). For example, the footnote to the national treatment standard provides as follows:

The Parties agree/ are of the understanding that a measure applied by a government in pursuance of legitimate policy objectives of public interest such as the protection of public health, human rights, labour rights, safety and the environment, although having a different effect on an investment or investor of another Party, is not inconsistent with national treatment and most favoured nation treatment when justified by showing that it bears a reasonable relationship to rational policies not motivated by preference of domestic over foreign owned investment. [Emphasis added.]

95 CPTPP (n 90) art 29.5. As explained in this Article, such measures may form the subject of inter-State dispute settlement under Chapter 28. 
In particular, the connection between public health and performance requirements is innovative: '[a] measure that requires an investment to use a technology to meet generally applicable health, labour rights, human rights, safety or environmental requirements shall not be construed to be inconsistent with paragraph 1 of this Article.' 96 Public health is not only a prominent reason to deny a finding of discriminatory treatment or expropriation, but the Norwegian Model BIT (2015) also contains a warning to States that it is inappropriate to encourage investment by relaxing domestic health, human rights, safety or environmental measures or labour standards' ${ }^{97}$ Finally, it is part of the Joint Committee's duties to 'discuss issues related to corporate social responsibility, the preservation of the environment, public health and safety, the goal of sustainable development, anticorruption, employment and human rights'.98

Virtually all recent Model BITs, such as the Indian Model BIT (2015) and the Dutch Model BIT (2018), contain some form of reference to public health, ${ }^{99}$ as do many newly concluded BITs and FTAs with an investment chapter. Often public health is stated as an objective in the Preamble, for example the Dutch Model BIT (2018) stipulates:

Considering that these objectives can be achieved without compromising the right of the Contracting Parties to regulate within their territories through measures necessary to achieve legitimate policy objectives, such as the protection of public health, safety, environment, public morals, labour rights, animal welfare, social or consumer protection or for prudential financial reasons. [Emphasis added.]

The Dutch Model BIT (2018) repeats this public health reference in subsequent articles, but doubts could arise as to the effect of such a reference if a treaty were to only include public health in its Preamble. Typically, preambles are 'regarded as legally non-binding or, more accurately perhaps, as not giving rise to enforceable rights and obligations'. ${ }^{100}$ It would hence be more difficult for a respondent State to successfully rely on a public health defence based solely on a treaty Preamble.

\section{B. Public Health as Part of the 'Right to Regulate'}

States have the right to regulate all matters in the territory under their effective control. This right does not need to be recognised in any treaty-it is part and

\footnotetext{
96 Agreement between the Kingdom of Norway and ... for the Promotion and Protection of Investments (Norwegian Model BIT (2015)) art $8<$ https://investmentpolicy.unctad.org/ international-investment-agreements/treaty-files/2873/download $>$.

98 ibid art 23(viii).

99 See Model Text for the Indian Bilateral Investment Treaty (Indian Model BIT (2015)) $<$ https://dea.gov.in/sites/default/files/ModelBIT_Annex_0.pdf $>$; and Netherlands Model Investment Agreement (Dutch Model BIT (2018)) < https://investmentpolicy.unctad.org/ international-investment-agreements/treaty-files/5832/download $>$.

100 J Klabbers, 'Treaties and Their Preambles' in MJ Bowman and D Kritsiotis (eds), Conceptual and Contextual Perspectives on the Modern Law of Treaties (Cambridge University Press 2018).
} 
parcel of what it means to be 'a State'. ${ }^{101}$ States might voluntarily limit their sovereign rights through the conclusion of particular treaties (for example, parties to the European Convention on Human Rights have to abolish the death penalty), ${ }^{102}$ but the default position is that wherever a right to regulate with regard to a specific issue has not been explicitly restricted through an international commitment, that State retains its full regulatory rights. As already observed two decades ago:

Nothing in the language of BITs purports to undermine the permanent sovereignty of States over their economies. It is, indeed, arguable that as a matter of international law the right of States to regulate their economies cannot be entirely alienated. ${ }^{103}$

Nevertheless, it was felt in some quarters ${ }^{104}$ that this right to regulate needed to be made explicit in investment treaties, but there is some divergence in the wording. For example, the Norwegian Model BIT (2015) states that:

Nothing in this Agreement shall be construed to prevent a Party from adopting, maintaining or enforcing any measure otherwise consistent with this Agreement that it considers appropriate to ensure that investment activity is undertaken in a manner sensitive to health, safety, human rights, labour rights, resource management or environmental concerns. ${ }^{105}$ [Emphasis added.]

This formulation, variations of which appear in several IIAs, does nothing more than reaffirm the primacy of the investment agreement in instances of tension with the right to regulate, ${ }^{106}$ although similar wording has had some interpretative relevance in the context of environmental measures. ${ }^{107}$ The preamble of the Canada-United States-Mexico Agreement (CUSMA) focuses even more on the fact that a treaty is meant to steer, to some extent, States' exercise of their regulatory power, as States Parties 'recognize their inherent right to regulate ... in accordance with the rights and obligations

101 See J Crawford, Brownlie's Principles of Public International Law (9th edn, Oxford University Press 2019) 431ff.

102 See European Parliament, 'The Death Penalty and the EU's Fight against It' (2019)<https:// www.europarl.europa.eu/RegData/etudes/ATAG/2019/635516/EPRS_ATA(2019)635516_EN. pdf $>$. $\quad 103$ V Lowe, 'Regulation or Expropriation?' (2002) 55 CLP 447, 451.

104 See Commission Staff Working Document, 'Report: Online Public Consultation on Investment Protection and Investor-to-State Dispute Settlement (ISDS) in the Transatlantic Trade and Investment Partnership Agreement (TTIP)' (European Commission, 13 January 2015) 18, 60, 72ff < https://trade.ec.europa.eu/doclib/docs/2015/january/tradoc_153044.pdf>.

105 Norwegian Model BIT (2015) (n 96) art 12.

106 See MN Kinnear, AK Bjorklund and JFG Hannaford, Investment Disputes under NAFTA: An Annotated Guide To NAFTA Chapter 11 (Oxford University Press 2006) 1114-15; L Johnson, L Sachs and N Lobel, 'Aligning International Investment Agreements with the Sustainable Development Goals’ (2019) 58 ColumJTransnatl L 101.

107 Al Tamimi v Sultanate of Oman, ICSID Case No ARB/11/33, Award (3 November 2015) paras 387-389. 
provided in this Agreement'. ${ }^{108}$ An earlier version of the Preamble read that the parties affirmed the 'inherent right to regulate and resolve to preserve the flexibility of the Parties to set legislative and regulatory priorities, in $a$ manner consistent with this Agreement', ${ }^{109}$ which 'essentially requires government measures to abide wholly with the rules set out in the [CUSMA]'. ${ }^{110}$ Arguably, such a disclaimer could be perceived as giving preference to the rights and obligations under the IIA, since public health measures have to be taken in accordance with the IIA-which begs the question: what if they are not?

Such disclaimers were not included in a number of other treaties, such as the investment chapter of the EU-Canada Comprehensive Economic and Trade Agreement (CETA), which states that:

For the purpose of this Chapter, the Parties reaffirm their right to regulate within their territories to achieve legitimate policy objectives, such as the protection of public health, safety, the environment or public morals, social or consumer protection or the promotion and protection of cultural diversity. ${ }^{111}$

Similar provisions were included in the EU-Singapore Investment Protection Agreement (IPA) and the EU-Vietnam IPA. ${ }^{112}$ Legally, it is doubtful whether the inclusion of such provisions (with or without disclaimers) adds anything to the existing rules and methods of interpretation, but it was viewed as politically important. ${ }^{113}$ However, Article 7 of TRIPS, entitled 'objectives' and couched in similar terms, was relied upon by the WTO Panel in Australia-Tobacco Plain Packaging with a view to ascertaining the circumstances in which the use of a trademark is 'unjustifiably encumbered' under Article 20 of TRIPS. For the Panel, Article 7 (together with Article 8, on 'principles') 'set out general goals and principles underlying the TRIPS

108 Canada-United States-Mexico Agreement (adopted 1 October 2018, entered into force 1 July 2020) (CUSMA) <https://www.international.gc.ca/trade-commerce/trade-agreements-accordscommerciaux/agr-acc/cusma-aceum/text-texte/toc-tdm.aspx?lang=eng $>$.

109 R Labonté et al., 'USMCA (NAFTA 2.0): Tightening the Constraints on the Right to Regulate for Public Health' (2019) 15:35 Globalization and Health $4 . \quad 110$ ibid.

111 Comprehensive Economic and Trade Agreement (CETA) between Canada, of the one part, and the European Union and its Member States, of the other part (adopted 30 October 2016, provisionally entered into force 21 September 2017) [2017] OJ L11/23 (CETA) art 8.9.1.

112 See Investment Protection Agreement between the European Union and its Member States, of the one part, and the Republic of Singapore, of the other part (adopted 15 October 2018, not yet in force) (EU-Singapore IPA) art 2.2; and Investment Protection Agreement between the European Union and its Member States, of the one part, and the Socialist Republic of Viet Nam, of the other part (adopted 30 June 2019, entered into force 1 August 2020) (EU-Vietnam IPA) art 2.2.

113 The States point out in their Joint Interpretative Instrument on the Comprehensive Economic and Trade Agreement (CETA) between Canada and the European Union and its Member States (adopted 14 January 2017) [2017] OJ L11/3 (CETA Joint Interpretative Instrument) 3, Point 2 (Right to Regulate), that 'CETA preserves the ability of the European Union and its Member States and Canada to adopt and apply their own laws and regulations that regulate economic activity in the public interest, to achieve legitimate public policy objectives such as the protection and promotion of public health, social services, public education, safety, the environment, public morals, social or consumer protection and the promotion and protection of cultural diversity.' 
Agreement, which are to be borne in mind when specific provisions of the Agreement are being interpreted in their context and in light of the object and purpose of the Agreement'. ${ }^{114}$ This suggests that adding policy objectives to treaties, such as protecting public health, may play a role in the interpretative exercise of some adjudicatory panels.

Rather than excluding investments in certain industries, such as tobacco manufacturing, through carve-outs (as was, for example, proposed by Malaysia in the CPTPP negotiations), treaty drafters across the globe seem to opt for the inclusion of general or article-specific exceptions in case of originneutral, science-based public health measures. ${ }^{115}$ Under the final text of the CPTPP, however, a Party may elect to deny the benefits of Section B of Chapter 9 (Investment) (ie the provisions concerning investor-State dispute settlement, not the substantive obligations) with respect to claims challenging tobacco control measures. ${ }^{116}$ Finally, an innovative provision in this regard can be found in the CPTPP Preamble, which not only refers to Parties' 'inherent right to regulate and resolve to preserve the flexibility of the Parties to set legislative and regulatory priorities, safeguard public welfare, and protect legitimate public welfare objectives, such as public health' but also 'their inherent right to adopt, maintain or modify health care systems'. ${ }^{117}$

\section{Public Health as Part of a General Exceptions Article}

One of the major choices to be considered by treaty drafters is whether to refer to public health in a general exceptions article, or to insert such a reference in individual substantive articles, or both. Canada seems to prefer the former option, as seen with the general exceptions provisions in the CanadaMoldova BIT (2018) and CETA. In its General Exceptions Article under Chapter 28, CETA provides that:

For the purposes of [...] Sections B (Establishment of investment) and C (Nondiscriminatory treatment) of Chapter Eight (Investment), Article XX of the GATT 1994 is incorporated into and made part of this Agreement. The Parties understand that the measures referred to in Article XX (b) of the GATT 1994 include environmental measures necessary to protect human, animal or plant life or health. $[\ldots]^{118}$

\footnotetext{
114 Australia-Tobacco Plain Packaging (n 34) para 7.2402. cf the finding that the Treaty of Amity, Economic Relations and Consular Rights between the United States of America and Iran (adopted 15 August 1955, entered into force 16 June 1957) 284 UNTS 93 art I, which provides that '[t]here shall be firm and enduring peace and sincere friendship' between the two States, was regarded 'as fixing an objective, in the light of which other Treaty provisions [we]re to be interpreted and applied': Oil Platforms (Iran v US) (Preliminary Objection, Judgment) [1996] ICJ Rep 803, 814, para 28.

115 AD Mitchell, T Voon and D Whittle, 'Public Health and the Trans-Pacific Partnership Agreement' (2015) 5 AsianJIL 279, 291.

116 CPTPP (n 90) art 29.5, fn 11.

117 ibid Preamble. See also Mitchell, Voon and Whittle (n 115) 290.

118 CETA (n 111) art 28.3.1.
} 
A similar provision is included in the Chapters on 'Exceptions and General Provisions' of CUSMA and CPTPP, with specific reference to GATT Article XX(b) and GATS Article XIV(b). ${ }^{119}$ A slightly different focus can be found in the Indian Model BIT (2015), which has a general exception for 'measures of general applicability' which 'ensur[e] public health and safety'. ${ }^{120}$ Several treaty drafters have opted for a mixed system, again illustrated by the Indian Model BIT (2015) which contains a general exceptions article as well as references to public health in its provisions on national treatment and expropriation; ${ }^{121}$ and CUSMA, which refers to public health in the general exceptions article as well as in the provisions on the scope of the investment chapter, expropriation, performance requirements and 'investment and environmental, health and other regulatory objectives'. ${ }^{122}$ Also, the EUVietnam IPA includes public health as one of the general exceptions, in addition to specific references in the articles on 'Investment and Regulatory Measures and Objectives' and expert reports, ${ }^{123}$ whereas the EU-Singapore IPA only contains a reference in the Preamble, and in its provisions on investment and regulatory measures, national treatment and taxation. ${ }^{124}$

\section{Public Health as Part of Article-Specific Exceptions or Carve-outs}

An alternative approach is the sole incorporation of specific exceptions which apply to a single article rather than to the entirety of an agreement. This appears to be the preferred option of the EU, as seen for example within the National Treatment article of the EU-Singapore IPA: ${ }^{125}$

Notwithstanding paragraphs 1 and 2, a Party may adopt or enforce measures that accord to covered investors and investments of the other Party less favourable treatment than that accorded to its own investors and their investments, in like situations, subject to the requirement that such measures are not applied in a manner which would constitute a means of arbitrary or unjustifiable discrimination against the covered investors or investments of the other Party in the territory of a Party, or is a disguised restriction on covered investments, where the measures are: $[\ldots]$

(b) necessary to protect human, animal or plant life or health;

119 CUSMA (n 108) art 32.1.3; CPTPP (n 90) art 29.1.2.

120 Indian Model BIT (2015) (n 99) art 16 (General Exceptions).

121 Indian Model BIT (2015) (n 99) arts 4 (National Treatment), 5 (Expropriation), 16 (General Exceptions). The incorporation of the police powers doctrine in Article 5 of the Indian Modal BIT is 'quite close to the language used by the Methanex tribunal', supporting the premise that newer treaties largely codify the earlier developments in the investment case law: P Ranjan, India and Bilateral Investment Treaties: Refusal, Acceptance, Backlash (Oxford University Press 2019) 325.

122 CUSMA (n 108) arts 14.2 (Scope), 14.8 (Expropriation), 14.10 (Performance Requirements), 14.16 (Investment and Environmental, Health and other Regulatory Objectives).

123 EU-Vietnam IPA (n 112) arts 2.2 (Investment and Regulatory Measures and Objectives), 3.52 (Expert Reports), 4.6 (General Exceptions).

${ }_{124}$ EU-Singapore IPA (n 112) arts 2.2 (Investment and Regulatory Measures), 2.3 (National Treatment), 4.6 (Taxation). ibid art 2.3.3. 
One effect of providing for host State justifications within a substantive provision could relate to the burden of proof. If these exceptions are interpreted in a manner such as the trade case law concerning Article 2.4 of the TBT Agreement, Articles 3.3 and 5.7 of the SPS Agreement, or Article 1102 of NAFTA, ${ }^{126}$ this would mean that the burden of proof remains with the claimant (the investor in this case). That approach is far from clear, however, as the text closely mirrors 'GATT Article XX' style exceptions; a tribunal could view the burden of proof as shifting towards the respondent (the State) once a prima facie case has been established. Under GATT Article XX, WTO Members have at times found it rather difficult to successfully discharge this evidentiary burden. ${ }^{127}$

As a result, embedding a public health exception within a substantive provision might make it easier for a State to justify that measure, insofar as a claimant would have to prove that a measure was not, for example, necessary to protect human health. ${ }^{128}$ However, this alternative could require inserting references to public health in each and every substantive provision (which none of the new generation treaties does), since an exception in one particular substantive standard only applies to that standard. Reflecting upon the inherent tension between, on the one hand, the 'intuitive appeal' in requiring a State to justify its regulatory action (given it is best placed to provide evidence relating to the 'nature, purposes and expected or actual effects of its action') and, on the other, the respect for sovereign regulatory freedom reflected in general international law, States may have to make a 'conscious decision' as to who bears the burden of proof and clearly articulate that decision in the treaty text. ${ }^{129}$

\footnotetext{
126 J Pauwelyn, 'Evidence, Proof and Persuasion in WTO Dispute Settlement: Who Bears the Burden?' (1998) 1 JIEL 227; M Grando, Evidence, Proof, and Fact-Finding in WTO Dispute Settlement (Oxford University Press 2009) 181-4; J Pauwelyn, 'Defences and the Burden of Proof in International Law' in L Bartels and F Paddeu (eds), Exceptions in International Law (Oxford University Press 2020) 92, fn 17; A Tsatsos, 'Burden of Proof in Investment Treaty Arbitration: Shifting?' (2020) 2 TDM <https://www.transnational-dispute-management.com/ article.asp?key=2731>; J Åhman, Trade, Health, and the Burden of Proof in WTO Law (Wolters Kluwer 2012).

127 Grando (n 126) 104.

128 As a variation on the general principle of actori incumbit probatio under international law, the WTO Appellate Body has accepted that once a party establishes an asserted fact on a prima facie basis, the burden falls on the other party to rebut that presumption: C Brown, A Common Law of International Adjudication (Oxford University Press 2007) 95-7. See also the discussion of Les Laboratoires Servier v Poland (n 51) in Section II.2; and Karkey Karadeniz Elektrik Uretim AS v Islamic Republic of Pakistan, ICSID Case No ARB/13/1, Award (22 August 2017) para 497 (accepting that the burden of proof shifts to a claimant once the respondent establishes prima facie evidence of corruption or fraud).

${ }^{129}$ CE Foster, Global Regulatory Standards in Environmental and Health Disputes: Regulatory Coherence, Due Regard, and Due Diligence (Oxford University Press 2021) 310. See also CE Foster, Science and the Precautionary Principle in International Courts and Tribunals: Expert Evidence, Burden of Proof and Finality (Cambridge University Press 2011) Chs 5-6 (addressing how the burden of proof may be allocated to accommodate the precautionary principle in the adjudication of international disputes involving scientific uncertainty).
} 
If treaty negotiators are of the opinion that exceptions should only apply to a select few articles, specific carve-outs may be more appropriate, like in the articles on national treatment and taxation in the EU-Singapore IPA. ${ }^{130}$ Such a calibrated approach has become typical in (indirect) expropriation provisions. For example, Annex 9-B of the CPTPP states:

Non-discriminatory regulatory actions by a Party that are designed and applied to protect legitimate public welfare objectives, such as public health, ${ }^{37}$ safety and the environment, do not constitute indirect expropriations, except in rare circumstances.

\footnotetext{
${ }^{37}$ For greater certainty and without limiting the scope of this subparagraph, regulatory actions to protect public health include, among others, such measures with respect to the regulation, pricing and supply of, and reimbursement for, pharmaceuticals (including biological products), diagnostics, vaccines, medical devices, gene therapies and technologies, health-related aids and appliances and blood and blood-related products.
}

However, general exceptions or carve-outs for public health may be more appropriate where drafters intend such provisions to apply to several articles and they do not see a need for a differentiated or calibrated approach in each particular article.

\section{E. GATT/GATS References and the Nexus requirement: 'Necessary to'}

Whether they opt for a public health exception in a general exceptions article or in individual substantive articles, treaty drafters may have to decide whether to explicitly incorporate GATT Article XX (or GATS Article XIV), whether to draft a public health exception that is closely or lightly modelled on GATT/ GATS without any express reference, or whether to devise a new formulation altogether. As seen above, the parties to CETA have opted for explicit incorporation, ${ }^{131}$ while the EU-Singapore IPA uses the same wording ('necessary to protect human, animal or plant life or health') ${ }^{132}$ but without any reference to GATT or GATS. As of yet, no treaty drafters have developed a completely new formulation.

Whether an explicit reference to GATT/GATS is included or not, the effect would seem to be the same. Perhaps, where such a reference is made, it could be easier to rely on GATT/GATS jurisprudence to interpret the required nexus between the measure at issue and the public health objective it is aimed to achieve. Most treaty drafters seem to have chosen to create a public health exception only for measures 'necessary to protect human, animal or plant life

130 EU-Singapore IPA (n 112) arts 2.3, 4.6.

131 CETA (n 111) art 28.3.

132 EU-Singapore IPA (n 112) art 2.3.3(b); Free Trade Agreement between the European Union and the Republic of Singapore (adopted 19 October 2018, entered into force 21 November 2019) [2019] OJ L294/3 art 8.62. 
or health'. ${ }^{133}$ This requires looking more closely at provisions that do include the 'necessary to' nexus requirement and then to assess its consequences in more depth.

Confusingly, many treaty drafters have adopted a mixed approach, referring to public health in various articles, some of which require necessity, while others do not. Article 8.9(1) of CETA, for example, sets out that 'the Parties reaffirm their right to regulate within their territories to achieve legitimate policy objectives, such as the protection of public health', which could be construed as requiring that a respondent State must merely intend to achieve a public health goal in order to exempt the measure from scrutiny.

However, the purpose of reaffirming the right to regulate in this Article allegedly:

... lies within the provision's interaction with the other provisions of the CETA Investment Chapter, mostly with the investment protection standards. In this respect, Article 8.9(1) CETA does not operate as a general exception clause excluding a Contracting Party's liability based on the CETA investment protection standards. Article 8.9(1) CETA rather serves interpretative purposes and adjudicators have to take the provision into account when an investment protection standard clashes with a host State's regulatory measure. CETA makes the inherent right to regulate of the contracting Parties the starting point of legal analysis. [Footnotes omitted; emphases added.] ${ }^{134}$

The term 'exception' is therefore unhelpful, at least in this context. What matters is that a respondent State cannot escape its obligations under CETA simply by invoking Article 8.9(1). Otherwise, the assertion of the 'right to regulate to achieve legitimate policy objectives' would suffice to dismiss any claim. The list in Article 8.9(1) is notably indicative ('such as'), so that any legitimate policy objective would suffice-but all State measures (are meant to) serve some legitimate policy objective, whether directly or not. Additionally, if Article 8.9(1) were a trump card, then paras 2-4 ('for greater certainty...') would seem redundant.

CETA's general exceptions article does require necessity to be established: 'nothing in this Agreement shall be construed to prevent the adoption or enforcement by a Party of measures necessary [...] to protect human, animal or plant life or health'. ${ }^{135}$ Potentially, the reason why necessity is required here is that this is an exception whereas the right to regulate is not. Moreover, the discrepancy could be justified because Article 28.3.2(b) (General Exceptions) only applies to Chapter 8, Sections B and C (Market access and performance requirements, and non-discriminatory treatment, ie

133 Dutch Model BIT (2018) (n 99) Preamble, art 2.2 (Right to Regulate) (emphasis added). See also CPTPP (n 90) arts 9.8, 9.10, Annex 9-B; CUSMA (n 108) art 14.10.3(c)(ii).

${ }^{134} \mathrm{~S}$ Schacherer, 'Article 8.9' in M Bungenberg and A Reinisch (eds), CETA Investment Law: Article-by-Article Commentary (Bloomsbury 2021) 165, para 14.

${ }^{135}$ CETA (n 111) art 28.3.2(b) (emphasis added). 
national treatment, most-favoured-nation treatment and treatment of senior management and boards of directors), whereas Article 8.9(1) applies to the entire Chapter. As this is not clear from the text, future jurisprudence should clarify this issue.

Another example of a BIT employing necessity as a nexus requirement for public health objections is the Dutch Model BIT (2018). It refers to necessity in its Preamble ('measures necessary to achieve legitimate policy objectives, such as the protection of public health') and the article on the right to regulate ("the right of the Contracting Parties to regulate within their territories necessary to achieve legitimate policy objectives such as the protection of public health') but not in the article on expropriation:

non-discriminatory measures of a Contracting Party that are designed and applied in good faith to protect legitimate public interests, such as the protection of public health, $[\ldots]$ do not constitute indirect expropriations. [Emphasis added.]

The reason for the absence of a necessity reference could be that this provision is a codification of police powers rather than a duplication of GATT/GATS provision on general exceptions. This again depends on whether the application of the police powers doctrine includes a necessity assessment - if it does, perhaps necessity does not need to be spelt out, because it will always be brought in as a matter of interpretation. The customary doctrine of police powers should not be subjected to a necessity assessment, unless this is explicitly stipulated in a treaty as a matter of lex specialis. The police powers doctrine has been commonly interpreted in practice as being subject to a reasonableness or proportionality analysis. ${ }^{136}$ The use of the formulation 'designed and applied' as seen in the Dutch model BIT (2018) can also be found in the expropriation standard in the CPTPP, CUSMA, the Indian Model BIT (2015) and the Ethiopia-Qatar BIT (2017). ${ }^{137}$ The latter treaty also uses this phrase when carving out an exception for public health measures in its most-favoured-nation treatment standard. ${ }^{138}$

As demonstrated by the WTO jurisprudence, a necessity requirement sets a high threshold for host States. ${ }^{139}$ Indeed, in WTO disputes, respondents have far

136 Tecmed $v$ Mexico (n 65) para 122.

137 CPTPP (n 90) art 9.8, Annex 9-B; CUSMA (n 108) art 14.17, Annex 14-B; Indian Model BIT (2015) (n 99) art 5.4; Agreement between the Government of the Federal Democratic Republic of Ethiopia and the Government of the State of Qatar for the Promotion and Reciprocal Protection of Investments (accepted 14 November 2017, not yet in force) (Ethiopia-Qatar BIT (2017)) art 9.

138 Ethiopia-Qatar BIT (2017) (n 137) art 7.

139 M Du, 'The Necessity Test in World Trade Law: What Now?' (2016) 15 ChineseJIL 817; DH Regan, 'The Meaning of 'Necessary' in GATT Article XX and GATS Article XIV: The Myth of Cost-Benefit Balancing' (2007) 6 WorldTR 347, 348; CP Bown and JP Trachtman, 'BrazilMeasures Affecting Imports of Retreated Tyres: A Balancing Act' (2009) 8 WorldTR 85, 12931; F Fontanelli, 'Necessity Killed Article XX: GATT and the Misleading Rhetoric about "Weighing and Balancing"” (2012) 5 European Journal of Legal Studies 39, 55; GATT Panel Report, United States-Section 337 of the Tariff Act of 1930, L/6439-36/S/345, adopted 7 
from always managed to justify a measure on this ground, so it can be predicted that, if the necessity test is applied in the same manner in investment disputes, host States might find it difficult to discharge the evidentiary burden of proof. ${ }^{140}$ It is uncertain whether this was the intention of the treaty drafters-on the contrary, based on public statements, ${ }^{141}$ the expressed intention would seem to have been that many, if not nearly all, public health measures would be justifiable on this basis. For this reason, the requirement that the measure be 'necessary' has been rightly criticised as overly onerous and showing insufficient deference to host State policies. For example, in his Separate Statement to the Award on the Merits in UPS $v$ USA, Ronald Cass found that necessity testing would 'greatly expand the power of NAFTA tribunals to evaluate the legitimacy of government objectives and efficacy of governmentally chosen means'. ${ }^{142}$

In any event, under GATT Article XX, the 'failure to establish that a challenged measure is justified by one of the general exceptions is typically due to discriminatory application of the measure contrary to the chapeau of the general exceptions', rather than the necessity requirement, as the conditions of the chapeau have been construed in a strict manner by WTO panels and the Appellate Body. ${ }^{143}$ WTO case law is deferential with respect

November 1989; GATT Panel Report, Thailand-Restrictions on Importation of and Internal Taxes on Cigarettes, DS10/R - 37S/200, adopted 7 November 1990); Appellate Body Report, KoreaMeasures Affecting Imports of Fresh, Chilled and Frozen Beef, WT/DS/161/AB/R, adopted 11 December 2000, para 166; Appellate Body Report, Brazil-Measures Affecting Imports of Retreaded Tyres, WT/DS332/AB/R, adopted 17 December 2007 (Brazil-Retreaded Tyres); Appellate Body Report, China-Measures Affecting Trading Rights and Distribution Services for Certain Publications and Audiovisual Entertainment Products, WT/DS363/AB/R, adopted 19 January 2010) (China-Audiovisual Products).

${ }^{140}$ The WTO Appellate Body's approach with respect to GATT Article XX(b), as set out in Appellate Body Report, European Communities-Measures Affecting Asbestos and Products Containing Asbestos, WT/DS135/AB/R, adopted 5 April 2001; and developed in Appellate Body Report, United States-Measures Affecting the Cross-Border Supply of Gambling and Betting Services, WT/DS285/AB/R, adopted 20 April 2005; and Brazil-Retreaded Tyres (n 139) 'shows deference and gives flexibility to national authorities', according to M Matsushita et al., The World Trade Organization: Law, Practice, and Policy (3rd edn, Oxford University Press 2015) 727-8. Ming Du argued that the WTO Appellate Body has relaxed the 'necessity' requirement (found in para (b) and others) in its more recent case law, notably in China-Audiovisual Products (n 139) and in Appellate Body Report, European Communities-Measures Prohibiting the Importation and Marketing of Seal Products, WT/DS400/AB/R, adopted 18 June 2014: Du (n 139) 819.

141 See eg CETA Joint Interpretative Instrument (n 113) 3, Point 2 (Right to Regulate).

142 United Parcel Service of America Inc v Government of Canada, ICSID Case No UNCT/02/1, Separate Statement of Dean Ronald A Cass (24 May 2007) para 117.

${ }^{143}$ T Voon, A Mitchell and J Munro, 'Importing WTO General Exceptions into International Investment Agreements: Proportionality, Myths and Risks' in L Sachs, L Johnson and J Coleman (eds), Yearbook on International Investment Law \& Policy 2017 (Oxford University Press 2019) 354, para 19.112. Sandford Gaines, focusing on para (g) (environmental measures), rather than para (b), argues that the WTO Appellate Body has read that provision generously, while reading the chapeau strictly. In other words, the chapeau becomes the focal point of the defensibility of measures: S Gaines, 'The WTO's Reading of the GATT Article XX Chapeau: A Disguised Restriction on Environmental Measures' (2001) 22 UPaJIntlEconL 739, 851-2. The same author points out that the WTO Appellate Body has held that 'the policy goal of a measure at issue 
to 'necessity' under GATT Article XX and while investment tribunals rely on such case law, they tend to construe necessity in a manner that restricts policy space more than the WTO Appellate Body does. ${ }^{144}$ The appropriateness of importing the principle of proportionality, especially stricto sensu, has been contested by commentators on WTO law and investment arbitration. ${ }^{145}$ However, the absence of a layer of general exceptions may create scope for investment treaty tribunals to impose a proportionality test in the application of substantive obligations. This would arguably be more intrusive than the general exceptions interpretation by the WTO Appellate Body (granting significant discretion to WTO members in choosing their preferred level of protection with respect to a given legitimate policy objective). ${ }^{146}$ Other scholars have questioned whether a balancing test - effectively a question of personal judgement - accords adjudicators an undesirable degree of discretion. ${ }^{147}$

Either way, 'the stringency of the test required to prove that a measure is "necessary", and what may constitute "arbitrary or unjustifiable discrimination between investments or between investors", are difficult questions that will determine the scope and utility of including these exceptions in IIAs'. ${ }^{148}$ Perhaps a clearer approach is presented in the wording of Article 2.2 of the TBT Agreement, which provides that 'technical regulations shall not be more trade-restrictive than necessary to fulfil a legitimate objective [inter alia, protection of human health], taking account of the risks nonfulfilment would create'. In applying this provision, the WTO Panel in Australia-Plain Packaging reaffirmed that it was not entitled to question the 'underlying purpose of the challenged measure', provided the objective was legitimate, but only 'the degree to which an equivalent contribution could be achieved through other less trade-restrictive measures attaining the same objective through different means'. ${ }^{149}$

cannot provide its rationale or justification under the standards of the chapeau': Appellate Body Report, United States-Import Prohibition of Certain Shrimp and Shrimp Products, WT/DS58/ AB/R, adopted 6 November 1998, para 149. The policy goal of a measure should be the reference point for justifiability of discrimination (Gaines, 778). Lorand Bartels concurred that the chapeau has gained a high profile because its conditions have proved decisive in a number of disputes: L Bartels, 'The Chapeau of the General Exceptions in the WTO GATT and GATS Agreements: A Reconstruction' (2015) 109 AJIL 95, 96. He does not, however, make any direct comparison with the requirements under the individual provisions or (b) in particular, although he points out that the WTO Appellate Body in Brazil-Retreaded Tyres (n 139) when examining the measure under (b), did not consider whether less discriminatory alternatives were available (which would have been a more stringent analysis than the one carried out).

144 Voon, Mitchell \& Munro (n 143) 321, para 19.29.

145 See eg P van den Bossche, 'Looking for Proportionality in WTO Law' (2008) 35 Legal Issues in Economic Integration 283; J Paine, 'Autonomy to Set the Level of Regulatory Protection in International Investment Law’ (2021) 70 ICLQ 697.

146 Voon, Mitchell and Munro (n 143) 353, para 19.107.

147 C Henckels, Proportionality and Deference in Investor-State Arbitration: Balancing Investment Protection and Regulatory Autonomy (Cambridge University Press 2015) 170.

148 Sheargold and Mitchell (n 34) 12.

149 Australia-Tobacco Plain Packaging (n 34) paras 7.195-7.198. 


\section{F. Self-Judging Necessity Tests}

To further confuse matters, some treaties contain self-judging necessity requirements. For example, the Indian Model BIT (2015) states: '[n]othing in this Treaty precludes the Host State from taking actions or measures of general applicability which it considers necessary'. Similarly, the CPTPP and CUSMA both stipulate:

Nothing in this Chapter shall be construed to prevent a Party from adopting, maintaining or enforcing any measure otherwise consistent with this Chapter that it considers appropriate to ensure that investment activity in its territory is undertaken in a manner sensitive to environmental, health or other regulatory objectives. ${ }^{150}$ [Emphasis added.]

This should avoid the application of an overly restrictive necessity test, but it risks foreclosing any kind of judicial review, no matter how marginal, so that even manifestly 'unnecessary' or 'inappropriate' measures would come to fall under the public health exception on the mere say-so of a respondent State. As the recent panel report in Russia-Traffic in Transit suggests, while such provisions may allow a larger margin of discretion for the invoking State, the adjudicatory body nevertheless retains the power to determine on an objective basis whether the requirements articulated therein are met. ${ }^{151}$ At the same time, investment tribunals have refused to read clauses as self-judging in the absence of clear indications to that effect, but have accepted that clear treaty language might indicate unbridled discretion on the part of invoking States. ${ }^{152}$ Additionally, with regard to self-judging provisions in CPTPP and CUSMA, it is unclear how tribunals, even if allowed to exercise some form of review, would have to measure 'appropriateness', which is arguably a differentpotentially laxer — standard than 'necessity'.

Beyond express treaty texts, the notion of necessity under general international law has previously posed interpretative pitfalls for investment arbitrators. For example, several annulment applications were made (with varying results) on the basis that tribunals had allegedly manifestly erred by integrating the conditions for the customary plea of necessity as a

150 CPTPP (n 90) art 9.16; CUSMA (n 108) art 14.16.

151 Panel Report, Russia-Measures Concerning Traffic in Transit (Russia-Traffic in Transit), WT/DS512/R, adopted 26 April 2019, para 7.82. See generally S Mantilla Blanco and A Pehl, National Security Exceptions in International Trade and Investment Agreements (Springer 2020) para 2.6.

${ }^{152}$ Deutsche Telekom AG $v$ The Republic of India, PCA Case No 2014-10, Interim Award (13 December 2017) para 231 ('[c]lear indications of the treaty would be required in order to infer that a provision is self-judging'); Mobil Exploration and Development Argentina Inc Suc Argentina and Mobil Argentina SA v The Argentine Republic, ICSID Case No ARB/04/16, Decision on Jurisdiction and Liability (10 April 2013) para 1041. cf Sempra Energy International v Argentina, ICSID Case No ARB/02/16, Award (28 September 2007) para 379 ('there can well be a presumption that they [treaty clauses] do not have such [self-judging] meaning in view of their exceptional nature'). 
circumstance precluding wrongfulness ${ }^{153}$ in their interpretation of a provision that exempted 'essential security measures' from the jurisdictional scope of the applicable treaty. ${ }^{154}$ Without any further guidance in the treaties themselves, therefore, many questions remain as to how necessity should be interpreted under these new IIAs. For example, to what extent are such provisions a reference to customary international law? What form should Least Restrictive Means (LRM) tests take under these agreements? ${ }^{155}$ Should there be a strict suitability test? What role (if any) should proportionality stricto sensu have?

It is unsurprising that some commentators are sceptical of the use of a proportionality analysis to 'second-guess the level of protection that a state has chosen as against the interest it is protecting'. ${ }^{156}$ If an impugned health measure were implemented in response to a public health emergency of international concern, such as the COVID-19 pandemic, an investment tribunal could for example refer to the proportionality test under the International Health Regulations as a relevant rule of international law in accordance with the principle of systemic integration. ${ }^{157}$

Furthermore, in treaties which include necessity as a requirement with regard to some, but not all, public health carve-outs, ${ }^{158}$ should a different test be applied depending on which article is invoked? This could create a situation in which a public interest measure prevails over investment protection with regard to the expropriation standard but not with regard to FET. Finally, it is

153 See International Law Commission, 'Articles on Responsibility of States for Internationally Wrongful Acts' (adopted 12 December 2001) UN Doc A/RES/56/83, Annex (ARSIWA) art 25.

154 See JE Viñuales, 'Defence Arguments in Investment Arbitration' (2020) 18 ICSID Rep 9, paras 26-32.

155 Labonté et al. (n 109) 11.

156 AD Mitchell, D Heaton and C Henckels, Non-Discrimination and the Role of Regulatory Purpose in International Trade and Investment Law (Edward Elgar 2016) 150.

157 Article 43 of the International Health Regulations (adopted 23 May 2005, entered into force 15 June 2007) 2509 UNTS 79 (International Health Regulations (2005)) stipulates that '[s]uch measures shall not be more restrictive of international traffic and not more invasive or intrusive to persons than reasonably available alternatives that would achieve the appropriate level of health protection'. See generally R Habibi et al., 'The Stellenbosch Consensus on Legal National Responses to Public Health Risks: Clarifying Article 43 of the International Health Regulations' (2020) IOLR < https://brill.com/view/journals/iolr/aop/article-10.1163-15723747-2020023/article10.1163-15723747-2020023.xml?language $=\mathrm{en}>54-60$.

158 Some might argue that 'exceptions' may be a more appropriate term than 'carve-outs', given that the latter is occasionally accorded a particular meaning akin to an outright exclusion (see also the discussion above with respect to CPTPP, Annex 9-B). While this terminology is neither established nor uncontroversial, in the Introduction to Exceptions in International Law (Oxford University Press 2020) (4-5), Lorand Bartels and Federica Paddeu write that there are two main types of 'exceptions': 'conditions limiting the scope of application of a rule (scope limitations), and conditions deeming a rule not to apply for independent reasons (exceptions provisions). In turn, scope limitations can be positive ("do not kill a person" necessarily excludes mosquitos) or negative ("do not kill animals except insects"), and they can also be internal or external ("the rule on killing animals does not apply to insects") - this can be called a carve-out.' Arguably, they observe, the right to adopt 'necessary measures', under the GATT or other areas of international law, is an exception to an otherwise applicable rule, rather than a limitation of the rule's scope. But equally, one could argue that these measures are indeed 'exceptions', in the sense of measures in principle covered, where certain government measures are possible, as long as they pursue public health objectives and are necessary. 
unclear how tribunals are expected to deal with measures which may well be 'designed and applied' to protect public health but that are ineffectual and disproportionate at doing so, or vice versa: measures that were not specifically designed or applied with a public health purpose in mind, but that do contribute to such objectives in practice.

In sum, the new generation of IIAs mentions public health in a number of different contexts, ranging from the right to regulate to article-specific exceptions and general exceptions. However, the consequences of these inclusions remain unclear with respect to the earlier line of arbitral case law.

\section{NEW TREATIES, DIFFERENT OUTCOMES?}

This section examines whether past cases would have been decided differently under the new generation of investment treaties. It also assesses whether existing concerns relating to public health and investment are alleviated through revised public health stipulations, and whether a new type of healthrelated investment dispute can be anticipated under these new treaties. Current circumstances demand sustained efforts by treaty negotiators to integrate foreign investment and public health in a balanced framework that safeguards reasonable regulatory measures without disincentivising private investment in health infrastructure. However, many of these insights could be transposed to provisions or disputes concerning other regulatory objectives.

\section{A. Existing Deference towards States' Regulatory Powers}

The new generation of IIAs and FTAs with an investment chapter is not revolutionary, but rather makes explicit the regulatory power of States under general international law that had already been inferred by investment tribunals operating under the first generation of treaties, as in Philip Morris $v$ Uruguay and Chemtura v Canada. For instance, investment tribunals have demonstrated how IIAs can be interpreted so as to accommodate States' need to regulate environmental protection in the pursuit of public health goals. Relying on investment protection to circumvent public health measures by arguing that they violate intellectual property rights has not been a successful endeavour for investors either. ${ }^{159}$ As a result, it would seem unlikely that any of the cases analysed above would have been differently decided under a 'new generation' treaty.

Nevertheless, from the perspectives of democratic legitimacy and coherent treaty interpretation, it is preferable that grounds which may well be (and have been in the past) determinative of the outcome of a case are explicitly provided for in the legal instrument that governs the case, ie the investment

\footnotetext{
159 Davison \& Emerton (n 34) 782. V Vadi, 'Energy Security v. Public Health? Nuclear Energy in International Investment Law and Arbitration' (2016) 47 GeoLJ 1069, $1114 \mathrm{ff}$.
} 
treaty. For this reason, revised treaty stipulations could alleviate existing concerns relating to public health and investment. Taking a lead from Philip Morris v Uruguay, investment treaties could explicitly affirm the discretion of host States to define public health goals and put in place measures to achieve them, as long as the relationship between means and ends is justifiable. States could also refer to specific health or environmental treaties as examples of international obligations that they might reasonably pursue without violating investment treaty standards. ${ }^{160}$ Tribunals can in any case be expected to continue to display deference towards the exercise of a State's regulatory powers even under BITs that do not explicitly refer to public health, such as the Switzerland-Uruguay BIT (1991). Due to this general assumption of deference to the host State, the demarcation of what constitutes a public health measure must be carefully made.

\section{B. Demarcation of Public Health Measures and Intellectual Property Rights}

Most new treaties that refer to 'public health' do not define what exactly is meant by this term. ${ }^{161}$ An exception in this regard is the CPTPP which stipulates that 'regulatory actions to protect public health include, among others, such measures with respect to the regulation, pricing and supply of, and reimbursement for, pharmaceuticals (including biological products), diagnostics, vaccines, medical devices, gene therapies and technologies, health-related aids and appliances and blood and blood-related products'. ${ }^{162}$ This is not an exhaustive list, so disputes might arise as to whether a particular measure qualifies as a public health measure under the applicable treaty. A concern could be that States might attempt to label any measure as a 'public health measure' in order to escape adjudicatory scrutiny, which has occurred in regard to taxation measures. For example, a recent open letter from over 1,200 US health experts deemed the 'right to protest' to be 'vital to the national public health'. ${ }^{163}$ Would this constitute a sufficiently scientific basis to argue that measures curtailing the right to protest could clash with 'public

\footnotetext{
160 In trade agreements containing both investment and environment chapters, moreover, obligations to adopt measures to fulfil obligations under specified multilateral environmental agreements could provide context for the interpretation of investment protection standards and a determination that an impugned measure was reasonably adopted: cf Philip Morris v Uruguay; Chemtura $v$ Canada. Under CUSMA, a failure to fulfil such environmental obligations is presumed to affect trade and investment between the Parties: art 24.8 CUSMA.

161 cf International Health Regulations (2005) (n 157) art 1 (which defines, inter alia, 'public health emergency of international concern' and 'public health risk').

${ }^{162}$ CPTPP (n 90) Annex 9-B. This wording was first included in Annex 8-A, fn 22 of the 2003 Australia-Singapore FTA. Other appearances include Australia's BITs with Hong Kong, Uruguay, and Peru; and Japan's BIT with Argentina.

163 J Ducharme, "“Protest is a Profound Public Health Intervention." Why So Many Doctors Are Supporting Protests in the Middle of the COVID-19 Pandemic' TIME (10 June 2020) <https://time. com/5848212/doctors-supporting-protests>.
} 
health' - and the latter should prevail? While this issue is unlikely to come up under an IIA, it illustrates how broad this concept can be.

An alternative way to tackle this question is to investigate what should not be protected by a general exception for public health. Arguably, such a list would include one or more of the following categories: measures unrelated to health, discriminatory measures, indirect expropriatory measures, measures that egregiously breach legitimate expectations (eg Vattenfall II), ${ }^{164}$ and measures that breach the principle of good faith, the rule of law, or constitute an abuse of due process. ${ }^{165}$ Such an approach is not unheard of. For example, a list detailing what is not covered by a particular provision was included in the Indian Model BIT (2015), which stipulates that 'non-discriminatory regulatory actions by a Party that are designed and applied to protect legitimate public welfare objectives such as public health, safety and the environment shall not constitute expropriation'. ${ }^{166}$

There are further, more controversial, categories that could be considered as pushing a measure outside the scope of protected public health measures, such as health-related measures which have no or little scientific basis. The Single Presentation Requirement (SPR) in Philip Morris v Uruguay is a good example of this. ${ }^{167}$ This requirement prevented manufacturers from marketing more than one variant of cigarette, which might suggest that one brand variant is less harmful than another. ${ }^{168}$ The Tribunal noted that its role was not to determine whether this measure actually had the intended effect of reducing cigarette consumption (a question on which the existing evidence was discordant); rather, what mattered was "whether it was a "reasonable" measure when it was adopted'. ${ }^{169}$ For the majority, the Respondent State was justified in relying on available, albeit inconclusive, evidence rather than conducting additional studies. ${ }^{170}$ The partially dissenting arbitrator started his analysis from the same standard on reasonableness but reached the opposite conclusion for want of firm evidence to support the utility of the measure. ${ }^{171}$

164 Vattenfall AB and others $v$ Federal Republic of Germany, ICSID Case No ARB/12/12. See L Bohmer, 'Breaking: Germany and Vattenfall Settle Long-Running Arbitration Dispute Arising from Nuclear Phase-Out' (IA Reporter, 5 March 2021) < https://www.iareporter.com/articles/breakinggermany-and-vattenfall-settle-long-running-arbitration-dispute-arising-from-nuclear-phase-out $>$.

165 See the decision in Yukos Universal Limited (Isle of Man) $v$ The Russian Federation, PCA Case No AA 227, Final Award (18 July 2014); U Kriebaum, 'Investment Arbitration - Rule of Law Demands of the Domestic Judiciary (Denial of Justice, Judicial Expropriation, Effective Means)' (SSRN, 10 January 2020) <https://papers.ssrn.com/sol3/papers.cfm? abstract_id=3517195>; J Paulsson, Denial of Justice in International Law (Cambridge University Press 2005).

166 Indian Model BIT (2015) (n 99) art 5.4. See for a similar provision: Dutch Model BIT (2018) (n 99) art 12.8 ('non-discriminatory measures of a Contracting Party that are designed and applied in good faith to protect legitimate public interests, such as the protection of public health [...], do not constitute indirect expropriations'). $\quad{ }_{167}$ Philip Morris v Uruguay (n 14) paras $107 \mathrm{ff}$.

${ }^{168}$ It was suggested that the marketing of multiple brand variants was launched in an attempt to circumvent an earlier ban on descriptors such as 'light': ibid para 114 .

169 ibid paras 408-409.

171 Philip Morris v Uruguay, Concurring and Dissenting Opinion (n 26) paras 157-159. 
The divergence between majority and minority in the application of a commonly known FET standard reflects the uncertainty about the precise content of certain investment obligations, ${ }^{172}$ potentially leading to a rigidity in reasoning when evaluating regulatory measures with a disputed scientific basis.

In order to better determine what merits protection, States should also define which intellectual property rights they wish to protect under their IIAs. ${ }^{173}$ Currently, it would seem to be assumed that all intellectual property rights are covered as soon as any reference to 'licences', 'returns' or even broadly 'assets' is included in the investment definition and therefore benefit from all procedural and substantive protection under the treaty. ${ }^{174}$ States could alternatively opt to restrict not only which intellectual property rights they wish to protect, but even (if they wish to maintain the current wide coverage) set additional requirements that need to be met before an investor can successfully invoke the IIA. This could, for example, put an end to the practice of registering a patent in a certain jurisdiction for the mere purpose of preventing manufacturing and export, while the investor never manufactures or distributes that drug in the registered territory. ${ }^{175}$

\section{An Alternative Nexus Requirement: 'Related to'}

As outlined above, the requirement that a measure be 'necessary to' achieve a public health objective may in effect exclude many public health measures from the scope of protection. An alternative would be to use the formulation 'related to', as found in GATT Article XX $(\mathrm{g})$ which is more flexible than the necessity requirement, ${ }^{176}$ although this could potentially protect an overly broad and vague array of measures. For example, mental health measures fall under the umbrella of being 'related to' public health, so the question could be whether a permit turning a piece of land into a public park is justifiable on the ground that it might improve the mental health of the neighbourhood's inhabitants? All manner of regulatory areas from anti-discrimination to culture, energy, the environment, finance, intellectual property, food labelling, labour rights, transport etc could be described as 'relating to public health'. Arguably, exceptions with nexus requirements of a mere relationship, such as that of GATT Article XX(g), 'hardly impose[...]' more discipline than the language

172 T Voon, 'Philip Morris v. Uruguay: Implications for Public Health' (2017) 18 Journal of World Investment and Trade 320, 330-1.

173 Vadi, Towards a New Dialectics (n 59) $166 \mathrm{ff}$.

174 B Mercurio, 'Safeguarding Public Welfare? Intellectual Property Rights, Health and the Evolution of Treaty Drafting in International Investment Agreements' in T Rensmann (ed), Mega-Regional Trade Agreements (Springer 2017) 246.

175 See M Temmerman, 'The Legal Notion of Abuse of Patent Rights' (May 2011) NCCR Trade Regulation Working Paper No 2011/23<https:/www.wti.org/media/filer_public/cf/eb/cfebd97f2f76-40ec-8c50-1259b81aa2a1/the_legal_notion_of_abuse_of_patent_rights.pdf $>$.

176 As advocated by, for example, Mercurio (n 174) 262. 
of carve-outs and reservations'. ${ }^{177}$ Yet the WTO Appellate Body has nevertheless found that, under Article $\mathrm{XX}(\mathrm{g})$, a 'substantial relationship' must exist between the measure and the conservation effort, so this requirement of a relationship is hardly perfunctory. ${ }^{178}$

Changing the current approach from providing an exception for public health measures that are 'necessary to' achieve a certain objective to one that also protects those that are merely 'related to' public health could, for example, change the outcome in cases such as Achmea $v$ Slovakia, where a sudden reversal of government policy regulating the health insurance market was considered a violation of the investor's rights. Leaving the compatibility with EU law aside, ${ }^{179}$ would any regulation of the health insurance market automatically be immune to claims because of its relationship to health? While such a policy reversal may not be 'necessary', or even counterproductive to achieve certain public health objectives, it would certainly be 'related to' health.

Of course, an appropriate balance would need to be found through treaty interpretation: while the use of 'necessary to' might exclude too many genuine public health measures from the scope of protection against investment claims, a change to protect all measures that are 'related to' public health might tilt the scales overly much in the opposite direction and take away protection from bona fide investments. ${ }^{180}$ For treaties that contain a necessity requirement, such a balance could be found by interpreting necessity not as demanding that the public health measure be the only possible measure to achieve a certain objective, but in light of its context, the best way (or at least 'a reasonable' way in light of all circumstances) of achieving it. This could be, for example, because other measures are overly onerous, expensive or less efficient. For treaties that contain no nexus requirement or that merely demand that the measure be 'related to' public health, a proportionality test could be applied (even in the absence of an explicit reference in the treaty).

Arguably, a similar concept of a balancing exercise lies behind the provision included in the Norwegian Model BIT (2015), discussed above (section III.1). According to that provision, measures taken in pursuance of the protection of public health (among other objectives) are not inconsistent with obligations

\footnotetext{
177 C Henckels, 'Should Investment Treaties Contain Public Policy Exceptions?' (2018) 59 BCLRev 2825, 2829.

178 Appellate Body Report, United States-Standards for Reformulated and Conventional Gasoline, WT/DS2/AB/R, adopted 20 May 1996, 19.

179 Slovak Republic v Achmea CJEU (n 42).

180 Corporate restructuring to gain treaty protection at a time when a dispute was already foreseeable would not constitute a bona fide investment: Philip Morris v Australia (n 17) para 554. But the fact that economic activities might impose health costs on the host State need not deprive an investment in such an industry of treaty protection: Philip Morris Brands Sàrl, Philip Morris Products SA and Abal Hermanos SA v Oriental Republic of Uruguay, ICSID Case No ARB/10/7, Decision on Jurisdiction (2 July 2013) paras 193-210.
} 
under investment law, as long as they bear 'a reasonable relationship to rational policies not motivated by preference of domestic over foreign owned investment'. ${ }^{181}$ However, where a measure is related to a genuine public health requirement, but is far more restrictive or creates far more damage than reasonably required to achieve the stated goal, the measure could fall outside of the public health exception.

The cognate notion of a 'rational relationship' has been developed in WTO law to assess a measure's otherwise discriminatory aspects and its underlying policy objectives, including under the chapeau to GATT Article XX. ${ }^{182}$ As discussed, many investment chapters in FTAs borrow the language of that chapeau to filter out measures that 'constitute arbitrary or unjustifiable discrimination between investments or between investors, or a disguised restriction on international trade or investment'. ${ }^{183}$ While this language could invite investment tribunals to adopt the WTO jurisprudence on rational relationships, it is important to underscore the difference between the notion of arbitrary or unjustified discrimination and the potentially broader qualification of a reasonable relationship as found in the Norwegian Model BIT (2015). The latter formulation could be more amenable to the vicissitudes of modern health regulation.

There are further reasons to avoid GATT language. A majority in Eco Oro v Colombia surprised many in its finding that an environmental exception based on GATT Article XX had to be interpreted in light of the FTA's dual purpose of investment and environmental protection, such that the so-called exception was merely 'permissive'. The Respondent had 'provided no justification as to why it [was] necessary for the protection of the environment not to offer compensation to an investor for any loss suffered' from its breach of the customary minimum standard in its arbitrary implementation of a prohibition on mining in a highaltitude wetland. ${ }^{184}$ States would do well to spell out clearly the consequences of a treaty exception, in light of the default position under general international law on which the majority relied. ${ }^{185}$ In his dissent, however, Philippe Sands found no breach of the minimum standard, opining that 'tribunals must be sensitive to the difficulties of government decisionmaking in the face of legitimate objectives that pull in different directions'

181 Norwegian Model BIT (2015) (n 96) art 3, fn 2 (emphasis added).

182 See Foster, Global Regulatory Standards in Environmental and Health Disputes (n 129) Ch 6.

183 See eg Bear Creek Mining Corporation v Republic of Peru, ICSID Case No ARB/14/21, Award (30 November 2017) paras 471-478.

${ }^{184}$ Eco Oro Minerals Corp v Republic of Colombia, ICSID Case No ARB/16/41, Decision on Jurisdiction, Liability and Directions on Quantum (9 September 2021) paras 826-837 (emphasis added).

${ }^{185}$ ARSIWA (n 153) arts 27 ('The invocation of a circumstance precluding wrongfulness ... is without prejudice to: ... (b) the question of compensation for any material loss caused by the act in question.') and 36.1 ('The State responsible for an internationally wrongful act is under an obligation to compensate for the damage caused thereby, insofar as such damage is not made good by restitution.'). 
amid climate change, biodiversity loss, and the COVID-19 pandemic, wherein 'governments struggle to find a way through the difficulties of protecting human health whilst also securing economic wellbeing'. ${ }^{186}$ It is precisely that type of sensitivity to reasonable regulation which many States would hope to codify in an exception for health measures.

One might object that an exception based on a reasonable relationship between means and ends simply duplicates the analysis that already occurs in the arbitral determination of whether a health measure violated the FET standard or constituted an unlawful expropriation. ${ }^{187}$ To ensure that an exception for measures that are reasonably related to public health effectively adds an additional layer of protection for regulatory prerogatives, States should clearly stipulate that such provisions operate as an exemption from the jurisdictional scope of an investment treaty. ${ }^{188}$ This way, they could foreclose an assessment of the impugned measure on the merits and allow a tribunal to resolve health-related investment disputes in a bifurcated hearing with less expense for both parties. A jurisdictional exemption for measures reasonably related to public health, moreover, would send a strong signal to arbitrators that the States parties do not seek to protect foreign investment at the expense of their fundamental duties to protect public health.

At the most extreme end of the spectrum, a State could even propose the selfjudging language of GATT Article XXI and the Indian Model BIT (2015) to exclude measures 'which it considers' reasonable for protection of public health. But it is highly doubtful whether a capital-exporting State would agree to such a sweeping provision and, in any event, such language would likely be conditioned by the obligation of good faith and a plausible relationship between the proffered interests and the contested measure. ${ }^{189}$

\section{CONCLUSION: FROM BALANCE TO SYNERGY?}

So far, this article has examined how tribunals and IIAs have sought to balance the protection of foreign investment and public health. The final question is whether, similar to the incentive given by the Kyoto Protocol to renewable energy investment, ${ }^{190}$ investment treaties and arbitration could serve to

\footnotetext{
186 Eco Oro Minerals Corp v Republic of Colombia, ICSID Case No ARB/16/41, Partial Dissent of Professor Philippe Sands QC (9 September 2021) para 28.

187 On recent constructions of reasonableness and proportionality in the case law, see F Ortino, The Origin and Evolution of Investment Treaty Standards: Stability, Value, and Reasonableness (Oxford University Press 2019) Ch 3.

188 See JE Viñuales, 'Seven Ways of Escaping a Rule: Of Exceptions and Their Avatars in International Law' in L Bartels and F Paddeu (eds), Exceptions in International Law (Oxford University Press 2020) 67-70. $\quad 189$ Russia-Traffic in Transit (n 151) paras 7.127-7.147.

190 F Baetens, 'Combating Climate Change through the Promotion of Green Investment: From Kyoto to Paris without Regime-Specific Dispute Settlement' in K Miles (ed), Research Handbook on Environment and Investment Law (Edward Elgar 2019). This article focuses on the Kyoto Protocol as a novel model for pursuing private investment to fulfil States' obligations. For later
} 
actively promote private investment in furtherance of global public health objectives, for example in the context of a global pandemic such as COVID-19. ${ }^{191}$ The potential for synergy between investment and other global public interest goals has already attracted scholarly analyses, ${ }^{192}$ but recent events have plainly sharpened awareness of the urgency of investing in a sustainable framework for global public health. Moreover, a holistic approach to foreign investment and public health would not treat health measures as exceptional and therefore avoid reinforcing:

... the perception that competition-distorting policies are per se illegal unless they meet the strictures of treaty-based and customary exceptions where the state bears the burden of persuasion. This is both normatively unsatisfying and a risky legitimation strategy. And the risk is especially pronounced where tribunals appear to overstep their bounds by reaching deep into the domestic regulatory apparatus or across international legal regimes. ${ }^{193}$

As an illustration: private companies such as AstraZeneca, Pfizer and Moderna are at the forefront of developing COVID-19 vaccines, but their research and the mass production of vaccines often does not take place in their respective countries of incorporation. In other words, they are foreign investors who might well wish to rely on IIAs to protect themselves against arguably unlawful behaviour of host States, for example where certain promises are made in order to steer pharmaceutical research in a particular direction and subsequently withdrawn. Compared to incentivisation schemes for renewable energy, which have generated a diverse jurisprudence under the Energy Charter Treaty as to whether a regulatory regime may give rise to legitimate expectations of investors, ${ }^{194}$ the public funding of research and development

development of this model in the context of the Paris Agreement, see H Zhang, 'Implementing Provisions on Climate Finance under the Paris Agreement' (2019) 9 Climate Law 21.

191 See eg K Dubas-Jakóbczyk et al., 'Health as an Investment in Poland in the Context of the Roadmap to Implement the 2030 Agenda for Sustainable Development and Health 2020' (WHO Regional Office for Europe 2018) <https:/www.euro.who.int/_data/assets/pdf_file/0010/385570/ health-polonia.pdf?ua=1>; 'Advancing Public Health for Sustainable Development in the WHO European Region' (WHO Regional Office for Europe 2018) < https://www.euro.who.int/_data/ assets/pdf_file/0004/380218/public-health-paper-eng.pdf>.

192 See eg AK Bjorklund, 'Sustainable Development and International Investment Law' in K Miles (ed), Research Handbook on Environment and Investment Law (Edward Elgar 2019); N Schrijver, '2019 AIIB Law Lecture: The Rise of Sustainable Development in International Investment Law' in P Quayle (ed), The Role of International Administrative Law at International Organizations (Brill 2020); A Bulovsky, 'The Over- and Under-Enforcement of Anti-Corruption Law in Investment Disputes and International Development' (2020) 9 CILJ 264; M-C Cordonier Segger, Crafting Trade and Investment Accords for Sustainable Development: Athena's Treaties (Oxford University Press 2021); S Stephenson and M-C Cordonier Segger (eds), Research Handbook on Investment Law and Sustainable Development (Edward Elgar forthcoming). For a cognate collection antedating the SDGs, see P-M Dupuy and JE Viñuales (eds), Harnessing Foreign Investment to Promote Environmental Protection: Incentives and Safeguards (Cambridge University Press 2013). $\quad 193$ Arato, Claussen \& Heath (n 1) 632.

194 See eg Eurus Energy Holdings Corporation v Kingdom of Spain, ICSID Case No ARB/16/4, Decision on Jurisdiction and Liability (17 March 2021) paras 314-317. 
as well as the subsequent purchase by governments of the resulting vaccines or medication will likely be grounded in specific administrative and contractual commitments to pharmaceutical companies protected by investment treaty standards such as FET. ${ }^{195}$ Would such companies, regardless of the particular circumstances of the case, be denied protection that is given to other foreign investors, simply because their work is related to public health? This could potentially lead to a stifling of private initiative. At a minimum, a balance needs to be struck. ${ }^{196}$

The Kyoto Protocol provides a model that goes beyond 'passively' protecting investor rights, but rather aims to actively harness the power of private capital flows to achieve public goals at the international level, more precisely, by promoting investment in renewable energy as a means to combat climate change. This model has been remarkably successful in the EU context (far more so than some States had expected and budgeted for). ${ }^{197}$ Similarly, wellregulated foreign investment that is protected by international law could be used to incentivise private investment in the public health sector. This is necessary, particularly in areas where little research is currently conducted, such as infectious diseases that mainly affect developing country populations (eg malaria, sleeping sickness or Chagas disease). ${ }^{198}$

Moreover, the Kyoto model could be not merely followed but improved upon: rather than only promoting private investment through a noninvestment-focused treaty (be it a climate change protocol or a public health agreement) while leaving disputes to be settled under IIAs (as is the case for renewable energy disputes), a new and ambitious public health agreement could be worked out. Such an agreement could facilitate foreign investment and provide a means for settling disputes between public health investors and host States. This would take such cases out of the 'general' investor-State dispute settlement system, and allow them to be decided by tribunals specialised in adjudicating public health and investment claims. ${ }^{199}$

195 See D Paolo Mancini, 'Vaccine Contracts Shrouded in Secrecy despite Massive Public Funding' Financial Times (23 November 2020) <www.ft.com/content/95c49b5a-f2c7-49a3$9 \mathrm{ac} 5-3 \mathrm{e} 7 \mathrm{a} 66 \mathrm{e} 3 \mathrm{ad} 6 \mathrm{~b}>$.

196 cf PV Investors v Kingdom of Spain, PCA Case No 2012-14, Final Award (28 February 2020) para 639 (wherein the Tribunal's application of the FET standard sought to strike 'the right balance between, on the one hand, the protection of investors who have committed substantial resources in a sector which continues to provide Spain with the environmental benefits of clean solar power, and, on the other hand, Spain's right to regulate and adapt its framework to changed circumstances, provided that right is exercised in a manner that is proportionate, reasonable, and non-arbitrary').

197 Baetens, 'Combating Climate Change through the Promotion of Green Investment' (n 190) 130 .

198 A Boutayeb, 'Developing Countries and Neglected Diseases: Challenges and Perspectives' (2007) 6 International Journal for Equity in Health 20.

$199 \mathrm{cf}$ the specialised optional rules developed by the PCA for the conciliation or arbitration of inter-State or investment disputes relating to the environment and/or natural resources: 'Environmental Dispute Resolution' (Permanent Court of Arbitration, 2021) < https://pca-cpa.org/ en/services/arbitration-services/environmental-dispute-resolution>. 
Such public health agreements could also address tensions between investment and current health present in current IIAs. For example, as analysed above (section III.2), the wording of several treaties including CUSMA would seem only to recognise States' right to take public health measures insofar as such measures are in accordance with the rights and obligations under the IIA. One of the main concerns is that intellectual property protection needs to be adequately balanced with access to medicine, in particular the cost of new drugs. When such balance is absent, many expropriation and FET claims could be brought, in particular when countries interpret their rights and obligations differently. The development of 'best practices' will take time, and also the requirements relating to transparency and participation in regulatory processes entail costs and delays, particularly for developing countries. ${ }^{200}$

CUSMA and CPTPP in particular have been criticised because their respective chapters on intellectual property rights allow access to medicines to be impacted by extensions of patent periods. ${ }^{201}$ Even though CUSMA and CPTPP acknowledge the 2001 Declaration on TRIPS and Public Health which provides for compulsory licensing of patented drugs, any invocation of such provisions is likely to face strong opposition. ${ }^{202}$ References to compliance with TRIPS may raise difficult questions in all IIAs, including with regard to judicial competence to consider the Doha Declaration. ${ }^{203}$ Also, while it is clearly the intention of States to ensure that compulsory licences issued in accordance with TRIPS, cannot be found expropriatory under an IIA, it is unclear whether compulsory licences that are inconsistent with TRIPs ought to be automatically considered in breach of the applicable IIA's expropriation standard. ${ }^{204}$

Moreover, the CUSMA chapters dealing with TBT, SPS and regulatory coherence seem to be aligned with the former President Trump Administration's 'deregulatory playbook by significantly increasing the influence of the corporate sector in regulation-making'. ${ }^{205}$ Further research

200 Mitchell, Voon and Whittle (n 115) 299ff.

201 Approximately 20 articles of the original Trans-Pacific Partnership (adopted 4 February 2016, not yet in force) have been temporarily postponed in the CPTPP, 11 of which deal with the strong commitments on intellectual property that were included upon demand of the United States over the course of the negotiations. The CPTPP thus delays requirements for member States to change their laws and practices and suspends the duration of copyright protection in case of unreasonable delays in licensing. Parties also will not have to extend protection terms from 50 to 70 years. The remaining postponed articles deal with investment, whereby the ability of foreign investors to sue the host State has been restricted. The 20 amendments are available here: New Zealand Ministry of Foreign Affairs and Trade, 'CPTPP vs TPP' < https://www.mfat.govt.nz/en/ trade/free-trade-agreements/free-trade-agreements-in-force/comprehensive-and-progressiveagreement-for-trans-pacific-partnership-cptpp/understanding-cptpp/cptpp-vs-tpp/>.

202 See CUSMA (n 108) art 20.1; CPTPP (n 90) art 18.6.1(b); Labonté et al. (n 109) 3. See further Declaration on the TRIPS Agreement and Public Health (adopted 14 November 2001) WTO Doc $\mathrm{WT} / \mathrm{MIN}(01) / \mathrm{DEC} / 2$.

${ }^{203}$ Sheargold and Mitchell (n 34) 20; CPTPP (n 90) art 18.6.1; CUSMA (n 108) art 20.1.

204 Mercurio (n 174) $252 . \quad{ }^{205}$ Labonté et al. (n 109) 12. 
could explore the balance between the potential efficiency gains from corporate participation in regulation (the regulatory coherence chapters of FTAs) versus the risk of increased costs, delays and appeals that such participation could entail. Moreover, CUSMA and the CPTPP require that where a body develops a standard for technical regulation, it has to allow persons 'of another Party to participate on no less favorable terms than its own persons in groups or committees of the body that is developing the standard'. ${ }^{206}$ If a global or multilateral public health agreement were to be developed, or even where public health considerations will be considered by bodies established under current treaties, this could create particular tensions for countries that are parties to CUSMA or CPTPP as well.

In sum, the importance of public health in international investment law is on the rise: not only has it been the focus of a number of international investment arbitrations, but it is becoming a fixture in the new generation of investment treaties. Whereas in the early years of investment arbitration, tribunals seemed largely to avoid discussing public health issues, recent tribunals have explicitly recognised that the regulation of health falls within States' police powers and that a margin of appreciation may be warranted to adapt to public health needs. In particular, the COVID-19 pandemic has showcased the importance for States not only to respond to health emergencies but also to harness public and private investment to construct resilient healthcare infrastructure accessible for everyone at all times. 